\title{
Feedforward Inhibition of the Rat Entorhinal Cortex and Subicular Complex
}

\author{
David M. Finch, ${ }^{1,2}$ Aiko M. Tan, ${ }^{2}$ and Masako Isokawa-Akesson ${ }^{2}$ \\ 'Department of Neurology, Reed Neurological Research Center, and 'Brain Research Institute, University of California, \\ Los Angeles, California 90024
}

\begin{abstract}
We used in vivo intracellular recording techniques in order to provide evidence about the source of postsynaptic inhibition in the rat entorhinal cortex and subicular complex. Several different structures in the basal forebrain and hippocampus were electrically stimulated in order to activate inhibition by different pathways. This allowed a test of 2 different neuronal circuit models: feedback inhibition, in which recurrent collaterals from principal cell axons excite a local population of inhibitory neurons, and feedforward inhibition, in which excitatory afferents activate the inhibitory neurons. In both models, inhibitory cell axons branch and contribute to the inhibition of a population of principal cells. In the feedback model, a good correlation between antidromic and inhibitory response latencies is predicted. The feedforward model predicts independent antidromic and inhibitory response latencies. In one particular model of feedforward inhibition, afferents excite both local inhibitory cells and principal cells. This model predicts a high correlation between principal cell EPSP and IPSP latencies.
\end{abstract}

The results showed no consistent relationship between the presence of antidromic action potentials and the presence of inhibition in response to stimulation of different sites. In addition, there was no correlation between antidromic and inhibitory response latencies. These results provide no clear support for the feedback model of inhibition. By contrast, there was a highly significant correlation between the latency of principal cell EPSPs and IPSPs, in support of a feedforward model of inhibition. Response latencies of candidate inhibitory neurons were also consistent with the feedforward model. The results provide evidence that an excitatory relay function of the entorhinal cortex and subicular complex is modified temporally by local, extrinsically activated inhibitory circuits.

Inhibition is prominent in entorhinal and subicular complex neurons in response to afferent stimulation. Effective stimulating loci include the hippocampus, dentate gyrus, subicular complex (for entorhinal neurons), and amygdala (Finch and Babb, 1980a, b; Colino and de Molina, 1986; Finch et al., 1986a, b). The usual response sequence is antidromic spike-EPSP-IPSP in neu-

\footnotetext{
Received Apr. 7, 1987; revised Oct. 26,1987; accepted Nov. 3, 1987.

Suported by NIH Grants NS 23074 and NS 16721. We thank our volunteer. Robert Gellibolian, for his help with this project.

Correspondence should be addressed to David M. Finch, Brain Research Institute, Center for the Health Sciences, University of California, Los Angeles, CA 90024 .

Copyright (c) 1988 Society for Neuroscience $0270-6474 / 88 / 072213-14 \$ 02.00 / 0$
}

rons that show all 3 response types (Finch and Babb, 1980b; Finch et al., 1986a, b). One possible neuronal circuit responsible for the inhibitory responses is feedback, or recurrent inhibition, as has been described for the hippocampus (see Andersen, 1975, for a review). However, recent neuroanatomical and neurophysiological evidence indicates that another type of inhibition, feedforward, is also present in several limbic structures. These include the hippocampus (Andersen, 1975; Alger and Nicoll, 1982; Buzsàki and Eidelberg, 1982; Ashwood et al, 1984; Buzsàki, 1984; Seress and Ribak, 1985), dentate gyrus (Buzsàki and Eidelberg, 1981, 1982; Seress and Ribak, 1984), and pyriform cortex (Satou et al., 1983; Haberly and Bower, 1984). We performed an in vivo neurophysiological study in the rat in order to determine a neuronal circuit model that would account for the response sequences observed in the entorhinal cortex and subicular complex. A variety of stimulation sites within the basal forebrain and the hippocampus was selected so that a latency analysis could be performed. No evidence for feedback inhibition was obtained, though its presence cannot be ruled out. By contrast, the results supported a model of feedforward inhibition, in which both inhibitory cells and principal cells are excited by afferent fibers. The results indicate that inhibition converges on entorhinal and subicular complex neurons from several different sources and that feedforward inhibition may be responsible for most of the inhibition in these structures.

\section{Materials and Methods}

In vivo electrophysiological techniques. Sprague-Dawley albino rats were anesthetized with chloral hydrate $(400 \mathrm{mg} / \mathrm{kg}$, i.p., supplemented by IM injections as necessary) and were placed in a stereotaxic frame. Recording techniques were similar to those used in our previous studies of the rat limbic system (e.g., Finch et al., 1986b). Briefly, 1-3 stimulating electrodes were placed stereotaxically, using the atlas of Paxinos and Watson (1982). The following structures were stimulated: angular bundle, dentate gyrus, diagonal band of Broca, fimbria, hippocampus (dorsal and ventral fields CA $1-4$ ), lateral olfactory tract, olfactory tubercle, primary olfactory cortex, ventral anterior nucleus of the thalamus, and nucleus accumbens. The structures were chosen because of their known direct or indirect connections with the entorhinal cortex and/or subicular complex. They gave a mixture of stimulating and recording loci that provided antidromic responses and short- and longlatency orthodromic responses. Neuronal recordings were obtained from the entorhinal cortex and from the posteroventral subicular complex, using fine micropipet electrodes of 50-100 $\mathrm{M} \Omega$ impedance, filled with $1.0 \mathrm{M}$ potassium citrate in saturated Fast green dye. Negative current (current clamp) of 0.1-5.0 nA was injected into 17 cells (out of 64) in order to maintain firing of action potentials. In 14 cells, pipets were filled with $1 \mathrm{M} \mathrm{KCl}$ to show the chloride-dependence of IPSPs.

Electrical stimulation was with $0.2 \mathrm{msec}$ pulses of $50-500 \mu \mathrm{A}$ intensity, isolated from ground. Most experiments were performed using a suprathreshold stimulus intensity of $500 \mu \mathrm{A}$. Physiological data were recorded on FM tape. Data were played back onto a Nicolet 1049A 


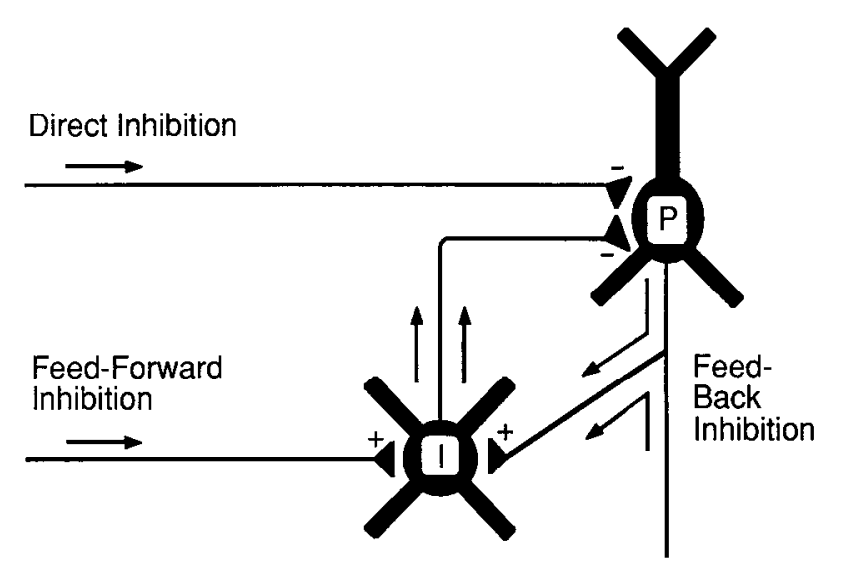

Estimates of Circuit Delays: $1.0 \mathrm{msec}$, synaptic delay

$3.0 \mathrm{msec}$, rise time of the EPSP to spike threshold

$0.5 \mathrm{msec}$, local propagation of the action potential

Figure 1. Neuronal model of 3 simple forms of inhibition. $P$, Principal cell; $I$, inhibitory cell. Plus signs indicate excitatory synapses, minus signs indicate inhibitory synapses. Assumed delay times in the local neuronal circuits are listed. The model assumes, but for simplicity of presentation does not show, that principal cells will contact more than one inhibitory neuron in the feedback circuit and that inhibitory neurons will contact more than one principal neuron.

digital oscilloscope, which was used for determining response types, latencies, and amplitudes, and for preparation of figures. Orthodromic excitatory responses were characterized by EPSPs and EPSP-triggered action potentials. Antidromic responses were characterized by constantlatency action potentials that were triggered in the absence of EPSPs. The antidromic responses showed no evidence of membrane charging that was present when cells were fired by intracellular current injections (Fig. 5). In some cases, hyperpolarizing current was injected intracellularly in order to test for the presence of an occult EPSP that might have triggered responses classified as antidromic; none were seen.

Recording sites were marked extracellularly by depositing the Fast green dye (50-100 $\mu \mathrm{A}$-min of negative current). Stimulating loci were marked by passing current $(50 \mu \mathrm{A}$ of current passed across the tips, 5 sec of each polarity) so that a Prussian blue reaction could be performed. After recording, the animals were perfused with saline and $10 \%$ formalin. Frozen sections were cut in the frontal plane at $100 \mu \mathrm{m}$, stained with cresyl violet, and coverslipped. Positions of the recording and stimulating sites were determined by microscopic examnination of the histological sections, and these loci were plotted on copies of the Paxinos and Watson (1982) atlas.

Neuronal circuit models. Three simple neuronal models of inhibition are shown in Figure 1. These models all assume that electrical stimulation will activate small populations of neurons and that some divergence of both inhibitory cell and principal cell output is present, due to local axonal branching. "Principal neurons" are operationally defined here as the most common neuronal type or types within a particular structure or layer. For example, the pyramids of the subiculum and of entorhinal layer III, and the star cells and small pyramids of entorhinal layer II would be operationally defined here as the "principal cells" of these regions. Principal cells cannot be defined only as projection neurons, since candidate inhibitory neurons within other limbic areas such as the hippocampus have been shown to have efferent projections (Alonso and Köhler, 1982; Babb et al., 1986; Schwerdtfeger and Buhl, 1986).

In the simplest model of Figure 1, direct inhibition, extrinsic inhibitory afferents synapse on principal neurons. Two types of indirect inhibition are also shown, feedback and feedforward. In the feedback, or recurrent model of inhibition, axonal collaterals of principal neurons excite a small population of local inhibitory neurons, which in turn inhibit the principal neurons. Principal neurons would be inhibited after they fired action potentials, whether the action potentials were elicited antidromically or orthodromically. The classical example is Renshaw inhibition in the spinal cord, which can be elicited antidromically by stimulation of ventral roots (Eccles, 1957). Another cxample is recurrent inhibition in the hippocampus, which can be activated by antidromic stimulation of pyramidal cell axons in a deafferented fornix preparation

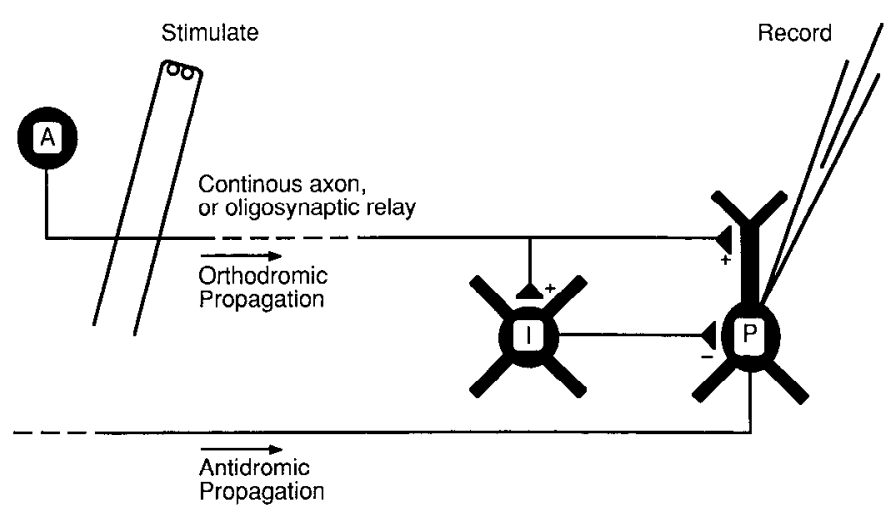

Figure 2. Feedforward inhibitory circuit in which afferent cells $(A)$ excite both principal cells $(P)$ and inhibitory cells $(I)$. The model assumes that electrical stimulation will activate a population of afferents and that inhibitory cells will contact more than one principal cell.

(Spencer and Kandel, 1961). In the general feedforward model of inhibition shown in Figure 1, extrinsic excitatory afferents directly excite local inhibitory neurons, which in turn inhibit the principal cells. As shown, the same inhibitory cell could participate in both feedback and feedforward inhibition, consistent with the findings of Lacaille et al. (1987) for hippocampal field CA1. Figure 2 shows one specific model of feedforward inhibition. In this circuit, excitatory afferents terminate on both principal neurons and local inhibitory neurons.

If predictions about response sequences and propagation times in these simple circuits are to be made, it is necessary to provide estimates for the duration of some neuronal events that cannot be directly observed. For this purpose, we assume that propagation of action potentials along a local axonal pathway takes $0.5 \mathrm{msec}$ and that synaptic delay - the time between transmitter release and the start of the postsynaptic potential-takes $1 \mathrm{msec}$. The rise time of the EPSP in candidate interneurons is assumed to be $3 \mathrm{msec}$, based on our neuronal recordings (Finch and Babb, 1980a; and Fig. 14 of the present paper). Note that propagation in multisynaptic relay pathways must include time for both synaptic delay and EPSP rise time.

Direct inhibition (Fig. 1) would be characterized by monosynaptic IPSPs in principal neurons. Assuming a conduction velocity of $1 \mathrm{~m} / \mathrm{sec}$ along afferent fibers would give a delay of $1 \mathrm{msec}$ for each $1 \mathrm{~mm}$ between stimulating and recording sites, plus $1 \mathrm{msec}$ for synaptic delay. No local candidate inhibitory neurons are necessary.

Feedback inhibition (Fig. 1) would be characterized by a disynaptic relay between antidromically elicited action potentials in principal neurons and their subsequent IPSPs. An estimate of the delay between the arrival of the antidromic spike in the principal neurons and the start of their IPSPS is $6 \mathrm{msec}$. This comprises delay in propagation along the principal cell axons from a local branch point to the inhibitory neurons $(0.5 \mathrm{msec})$; synaptic delay for the excitatory principal cell-inhibitory cell synapses ( $1 \mathrm{msec}$ ); rise of the EPSP to the threshold for spike initiation in the inhibitory neurons $(3 \mathrm{msec})$; propagation along the inhibitory cell axons to the principal cells $(0.5 \mathrm{msec})$; and synaptic delay for the inhibitory cell-principal cell synapses $(1 \mathrm{msec})$. Orthodromically initiated action potentials would also result in inhibition, after about the same delay.

Feedforward inhibition (Fig. 1) would be characterized by a monosynaptic relay between EPSP-triggered action potentials in candidate inhibitory neurons and subsequent IPSPs in principal neurons. Antidromic spikes would play no role in exciting the inhibitory neurons. An estimate of the delay from the start of the inhibitory cell EPSP to the start of the principal cell IPSP is $4.5 \mathrm{msec}$. This comprises rise time of the EPSP ( $3 \mathrm{msec}$ ); propagation along the inhibitory cell axons to the principal cells $(0.5 \mathrm{msec})$; and synaptic delay for the inhibitory cellprincipal cell synapses $(1 \mathrm{msec})$.

The specific model of feedforward inhibition shown in Figure 2 would be characterized by a monosynaptic delay time between principal cell EPSPs and IPSPs. This is the case, because physiological activation of the excitatory afferents would elicit EPSPs in both principal neurons and inhibitory neurons at about the same latency. An estimate of the delay between the arrival of the EPSPs in the principal cells and their subsequent IPSPs is thus $4.5 \mathrm{msec}$, the same as the delay from the start 
of the inhibitory cell FPSP to the start of the principal cell IPSP (previous paragraph).

Note that the latency relationships in the feedforward models would apply whether the EPSPs were elicited monosynaptically or oligosynaptically. Note also that the principal cell might or might not show an antidromically elicited action potential, depending upon whether its axon was also stimulated. However, this antidromic action potential would not contribute in any way to the IPSP. Accordingly, antidromic action potentials would not be required to show a consistent temporal correlation with inhibitory responses.

It is apparent from the above estimates that there is overlap in some of the feedback and feedforward model predictions, particularly for a short-latency monosynaptic excitatory input and short-latency antidromic activation. However, for short-latency antidromic and longlatency orthodromic activation, the models predict distinct latency relationships. For example, assume a (short) $1 \mathrm{msec}$ average antidromic spike latency in a population of cells in response to stimulation of a given structure, and a (long) $15 \mathrm{msec}$ EPSP latency due to excitatory afferents activated by the same stimulating electrode. The long-latency EPSP could reflect slowly conducting afferent fibers or a multisynaptic afferent pathway. The feedback model of inhibition would predict IPSPs at a latency of $7 \mathrm{msec}$ (that is, $6 \mathrm{msec}$ after the arrival of the antidromic spikes, see above). The EPSP would arrive at $15 \mathrm{msec}$, during the IPSP. It would therefore be occult or would perhaps be seen as a brief depolarizing component of the IPSP. On the other hand, the feedforward model of inhibition would predict IPSPs at a latency of $19.5 \mathrm{msec}$ (that is, $4.5 \mathrm{msec}$ after the start of the EPSPs). The distinct predictions allow an experimental test of feedforward inhibition.

These arguments require that the propagation time estimates in the simple neuronal circuits of Figures 1 and 2 are accurate. Our assumption of a $1.5 \mathrm{msec}$ delay from principal cell action potentials to inhibitory cell EPSPs in a fecdback circuit $(0.5 \mathrm{mscc}$ local propagation time plus $1 \mathrm{msec}$ synaptic delay, see above) is reasonable on the basis of direct experimental observations in another limbic structure, the hippocampus. Knowles and Schwartzkroin (1981) recorded simultaneously from pairs of CAl inhibitory neurons and principal cells in the slice preparation. Measurements from their Figure 4 show a delay of $1.6 \mathrm{msec}$ from the principal cell spike to the inhibitory cell EPSP, virtually the same as our assumed $1.5 \mathrm{msec}$. Our assumption of a $1.5 \mathrm{msec}$ delay from inhibitory cell spike to principal cell IPSP is also reasonable on the basis of experimental observations. Miles and Wong (1984) recorded simultaneously from pairs of CA3 neurons in the hippocampal slice preparation. They showed, for 2 cases in which there was evidence for direct, monosynaptic coupling, delays of $0.7 \mathrm{msec}$ (their Fig. 3C) and $3.6 \mathrm{msec}$ (measurement taken from their Fig. 6E) from candidate inhibitory cell spikes to principal cell IPSPs. These data overlap our 1.5 msec assumed value, as well as our average experimentally obtained value of $3.3 \mathrm{msec}$ (Table 3 ). Although our data were not obtained from simultaneous recordings, each inhibitory cell-principal cell pair was activated by identical parameters of electrical stimulation. Our assumption of a total delay of $6 \mathrm{msec}$ from principal cell action potentials to principal cell IPSPs in a feedback circuit is reasonable as well. Miles and Wong (1984) reported, for 2 cases, delays of 3.1 and $7 \mathrm{msec}$ from principal cell spike to principal cell IPSP in a feedback inhibitory circuit.
These latencies overlap our assumed value of $6 \mathrm{msec}$. Thus, the circuit delays assumed for the models shown in Figures 1 and 2 are consistent with experimental observations.

\section{Results}

\section{Neuronal recordings}

Recordings were obtained from 64 neurons within the entorhinal cortex and subicular complex of 33 different rats. Table 1 summarizes the electrophysiological properties obtained from these neurons. Depending upon the amplitude of the action potential, these were classified as extracellular $(<20 \mathrm{mV}$, with no distinct baseline shift; $n=2)$, "quasi-intracellular" (20-39 $\mathrm{mV}, n=16$, all but 2 of which showed clear synaptic potentials) or intracellular [ $\geq 40 \mathrm{mV}, n=46$, based on the spike amplitude criterion used by Kandel et al. (1961) for in vivo intracellular recordings from cat hippocampal pyramidal neurons]. Some of the "quasi-intracellular" recordings may represent dendritic penetrations (Llinás and Sugimori, 1984; Woody et al., 1984). Sixteen out of 28 subicular complex neurons, and 17 out of 35 entorhinal neurons showed spontaneous bursts, and individual neurons could show both single spikes and bursts (e.g., Fig. 3B2). Most neurons in these experiments showed basically similar physiological properties (most characteristically action potentials whose descending phase did not obviously overshoot baseline and whose responses to EPSPs was at most a single spike), and they will be referred to tentatively as "principal neurons." A few neurons showed physiological properties that have been previously associated with inhibitory neurons (most characteristically brief action potentials $-0.5 \mathrm{msec}-$ whose descending phase overshot baseline and whose responses to EPSPs was a burst of spikes), and they will be referred to tentatively as candidate inhibitory neurons.

\section{Responses to stimulation}

Table 2 summarizes the responses and response latencies of the cells in this study. Individual cells showed various combinations of antidromic responses, EPSPs, and IPSPs; and in cells showing all 3 response types, this was the usual response order. Figures 3 and 4 show examples in a layer II entorhinal neuron and in a subicular neuron, respectively. These principal neurons were capable of producing multiple action potentials in response to intracellular current injection (Fig. 5) but never did so when they were activated synaptically.

There was not a necessary correspondence between the pres-

Table 1. Electrophysiological properties of subicular and entorhinal neurons

\begin{tabular}{|c|c|c|c|c|c|c|c|c|c|c|c|c|}
\hline & \multicolumn{6}{|c|}{ Subicular complex } & \multicolumn{6}{|c|}{ Entorhinal cortex } \\
\hline & \multicolumn{3}{|c|}{ Quasi-intracellular } & \multicolumn{3}{|c|}{ Intracellular } & \multicolumn{3}{|c|}{ Quasi-intracellular } & \multicolumn{3}{|c|}{ Intracellular } \\
\hline & $n$ & Mean & Range & $n$ & Mean & Range & $n$ & Mean & Range & $n$ & Mean & Range \\
\hline Spike amplitude (mV) & 7 & 29 & $20-37$ & 12 & 47 & $40-61$ & 5 & 28 & $20-38$ & 16 & 51 & $40-73$ \\
\hline Resting potential $(-\mathrm{mV})$ & 3 & 31 & $42-23$ & 12 & 48 & $70-27$ & 3 & 43 & $60-32$ & 12 & 48 & $73-32$ \\
\hline Spike duration (msec) & 7 & 1.2 & $0.6-1.8$ & 12 & 1.0 & $0.5-1.9$ & 5 & 1.3 & $1.1-1.5$ & 16 & 1.2 & $0.5-2.4$ \\
\hline Spontaneous rate (spikes/sec) & 7 & 10 & $4-16$ & 12 & 11 & $0-25$ & 5 & 10 & 4-17 & 16 & 10 & $1-24$ \\
\hline Conduction velocity $(\mathrm{m} / \mathrm{sec})$ & \multicolumn{3}{|c|}{ Pooled $\rightarrow$} & 47 & 16 & $2-29$ & \multicolumn{3}{|c|}{ Pooled $\rightarrow$} & 36 & 13 & $2-26$ \\
\hline
\end{tabular}

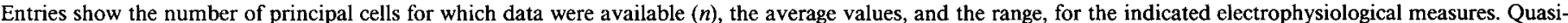

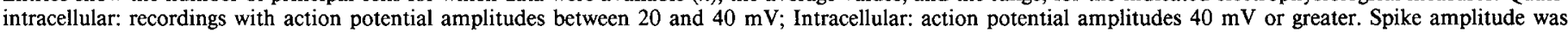

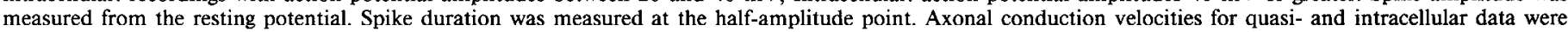

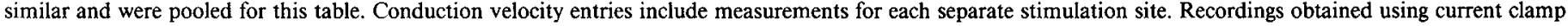
are not included under Spontaneous rate. 

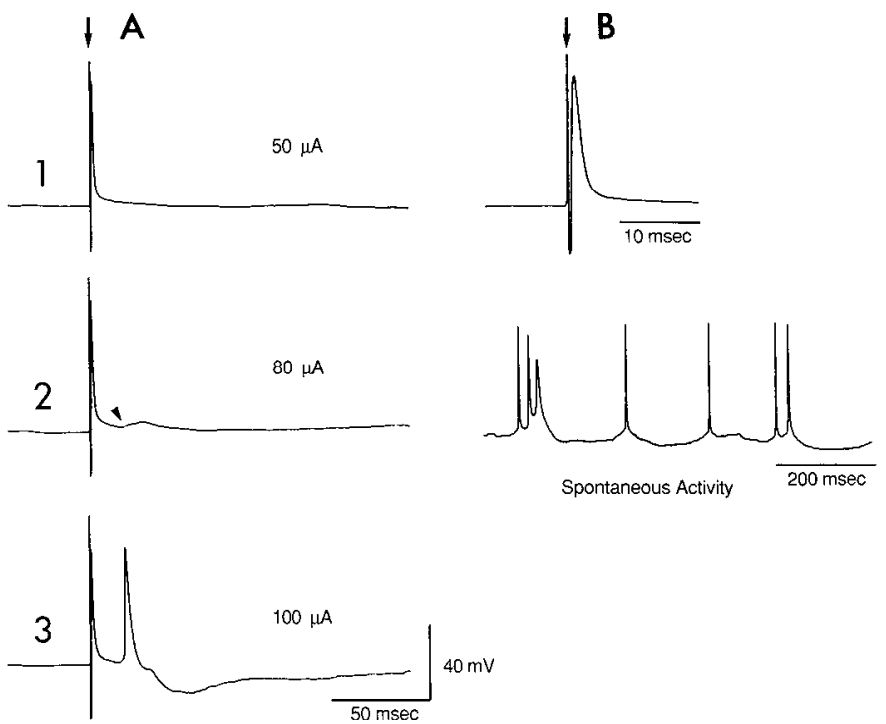

Figure 3. Responses in an entorhinal layer II neuron after CA2 stimulation. Arrows indicate stimulus artifact. Arrowhead (A2) indicates a subthreshold EPSP in response to $80 \mu \mathrm{A}$ stimulation. Note that antidromic activation was present with a stimulus current as low as $50 \mu \mathrm{A}$ $(A 1, B I)$, but a clear IPSP was not present until the stimulus current was increased to $100 \mu \mathrm{A}(A 3)$. Rat DG6, cell 3.

ence of antidromic spikes and the presence of inhibition. Most notably, with lateral olfactory tract (LOT) stimulation, 9 of 12 subicular complex neurons $(75 \%)$ showed an antidromic action potential, but only 1 of $12(8 \%)$ showed an IPSP (Table 2 ). This is contrary to the prediction of the feedback model of inhibition.

There was also no consistent relationship between the latency of antidromic action potentials and IPSPs, also contrary to the prediction of the feedback model of inhibition. Figure 6 shows examples, with a layer II and with a layer V entorhinal neuron: Cell 7 from rat DB66 (Fig. 6, row 1) showed a short-latency $(0.6 \mathrm{msec})$ antidromic spike and a short-latency $(2.7 \mathrm{msec})$ IPSP. The proximity of the stimulating and recording sites accounts
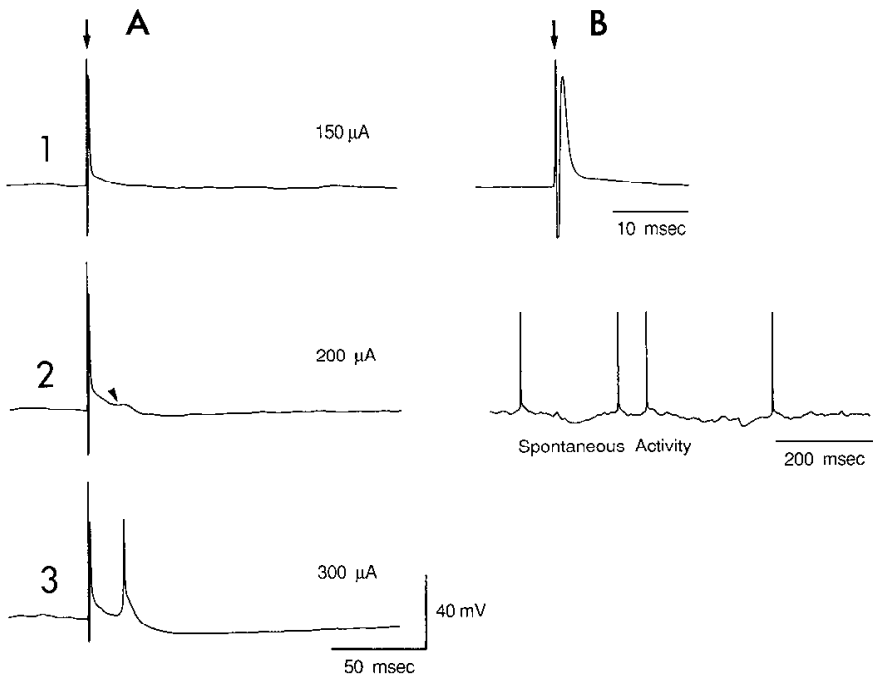

Figure 4. Responses in a subicular neuron after CA3 stimulation (arrow). Antidromic activation alone was present with a stimulus current of $150 \mu \mathrm{A}(A 1, B 1)$. A small EPSP (arrowhead) and IPSP were also present when the stimulus current was increased to $200 \mu \mathrm{A}(A 2)$. The EPSP reached threshold with $300 \mu \mathrm{A}$ of stimulus current, and the IPSP became larger and longer. Rat DB58, cell 7.

for the short latency of the IPSP: The estimated distance between these 2 loci was $0.7 \mathrm{~mm}$. By contrast, cell 9 from rat HP3 (Fig. 6 , row 2) also showed a short-latency antidromic spike $(0.5$ $\mathrm{msec})$ but a long-latency $(16.1 \mathrm{msec})$ IPSP. In this case, the stimulating and recording loci were separated by about $8 \mathrm{~mm}$. The experimentally obtained IPSP response latency $(16.1 \mathrm{msec})$ is too long to be explained by the feedback model shown in Figure 1, which only involves 2 synaptic relays after antidromic activation: the estimated IPSP latency under the feeback inhibition model is only $6.6 \mathrm{msec}(6 \mathrm{msec}$ as stated in Neuronal circuit models, above, plus $0.6 \mathrm{msec}$ for the antidromic spike latency). The pipet for this cell was filled with $\mathrm{KCl}$. Injection of chloride inverted the IPSP (Fig. 6, 3A), indicating that the po-

Table 2. Number of responding cells, and response latencies, of entorhinal and subicular complex neurons after stimulation of afferent and efferent pathways

\begin{tabular}{|c|c|c|c|c|c|c|c|}
\hline $\begin{array}{l}\text { Stim. } \\
\text { site }\end{array}$ & Rec. site & $\begin{array}{l}\text { Cells } \\
\text { tested } \\
(n) \\
\end{array}$ & $\begin{array}{l}\text { Antidromic } \\
\text { (latency) }\end{array}$ & EPSP (latency) & $\begin{array}{l}\text { Orthodromic } \\
\text { spike (latency) }\end{array}$ & IPSP (latency) & $\begin{array}{l}\text { No } \\
\text { response }\end{array}$ \\
\hline \multirow[t]{2}{*}{$\mathrm{AB}$} & II & 4 & $2(0.8 \pm 0)$ & $0(-)$ & $0(-)$ & $4(2.7 \pm 0.1)$ & 0 \\
\hline & SUB & 4 & $4(0.7 \pm 0.1)$ & $2(6.3 \pm 1.8)$ & $0(-)$ & $3(6.9 \pm 2.8)$ & 0 \\
\hline \multirow[t]{2}{*}{ Acc } & II & 8 & $3(0.6 \pm 0)$ & $0(-)$ & $0(-)$ & $3(24.7 \pm 9.5)$ & 2 \\
\hline & III, V & 2 & $2(0.6 \pm 0.1)$ & $0(-)$ & $0(-)$ & $1(19 \pm 0)$ & 0 \\
\hline \multirow[t]{3}{*}{ DBB } & II & 11 & $8(0.6 \pm 0.1)$ & $2(19.5 \pm 6.4)$ & $1(27.0 \pm 0)$ & $5(52.0 \pm 26.9)$ & 3 \\
\hline & III, V & 2 & $1(0.7)$ & $0(-)$ & $0(-)$ & $0(-)$ & 1 \\
\hline & SUB & 17 & $13(0.7 \pm 0.1)$ & $0(-)$ & $0(-)$ & $10(11.6 \pm 1.4)$ & 2 \\
\hline \multirow[t]{3}{*}{ IIPC } & II & 14 & $13(0.6 \pm 0.1)$ & $5(15.4 \pm 5.7)$ & $2(12.8 \pm 1.5)$ & $9(17.3 \pm 9.9)$ & 0 \\
\hline & III, V & 5 & $4(0.7 \pm 0.2)$ & $0(-)$ & $0(-)$ & $3(10.6 \pm 6.8)$ & 0 \\
\hline & SI JB & 18 & $13(0.6 \pm 0.1)$ & $7(13.7 \pm 3.6)$ & $7(15.3 \pm 3.5)$ & $12(18.7 \pm 4.5)$ & 2 \\
\hline \multirow[t]{3}{*}{ LOT } & II & 16 & $3(0.6 \pm 0.2)$ & $4(11.9 \pm 2.8)$ & $2(16.4 \pm 4.8)$ & $13(22.3 \pm 7.4)$ & 2 \\
\hline & III, V & 3 & $0(-)$ & $1(-)$ & $0(-)$ & $2(33.4 \pm 16.5)$ & 1 \\
\hline & SUB & 12 & $9(0.6 \pm 0.1)$ & $0(-)$ & $0(-)$ & $1(-)$ & 3 \\
\hline
\end{tabular}

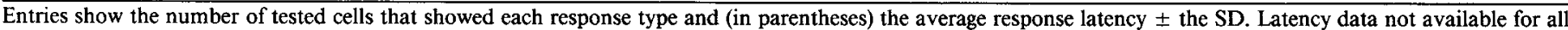

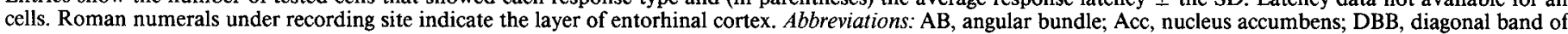

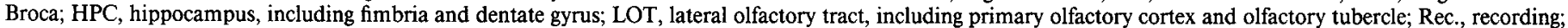
Stim., stimulation; SUB, subicular complex. 


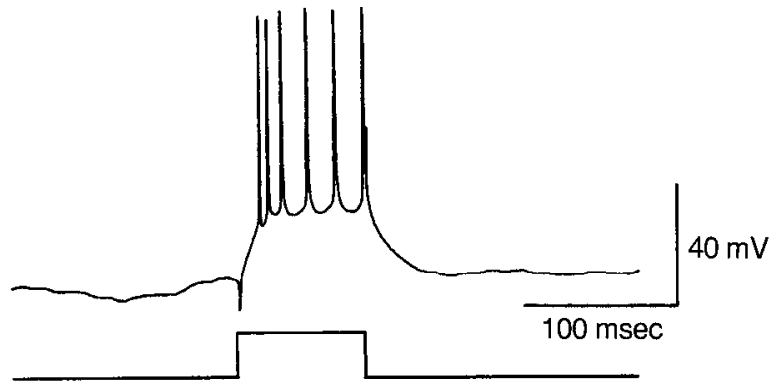

1 nA Depolarizing Current

Figure 5. Response of an entorhinal layer II principal neuron to intracellular current injection. The cell was capable of firing multiple action potentials in response to the stimulus. This contrasts with the orthodromic excitatory responses to stimulation of afferent pathways, in which only one action potential was evoked (Figs. 3, 4). The slow charging and discharging apparent here at stimulus onset and offset were not seen with antidromic activation. Rat DB76 cell 9.
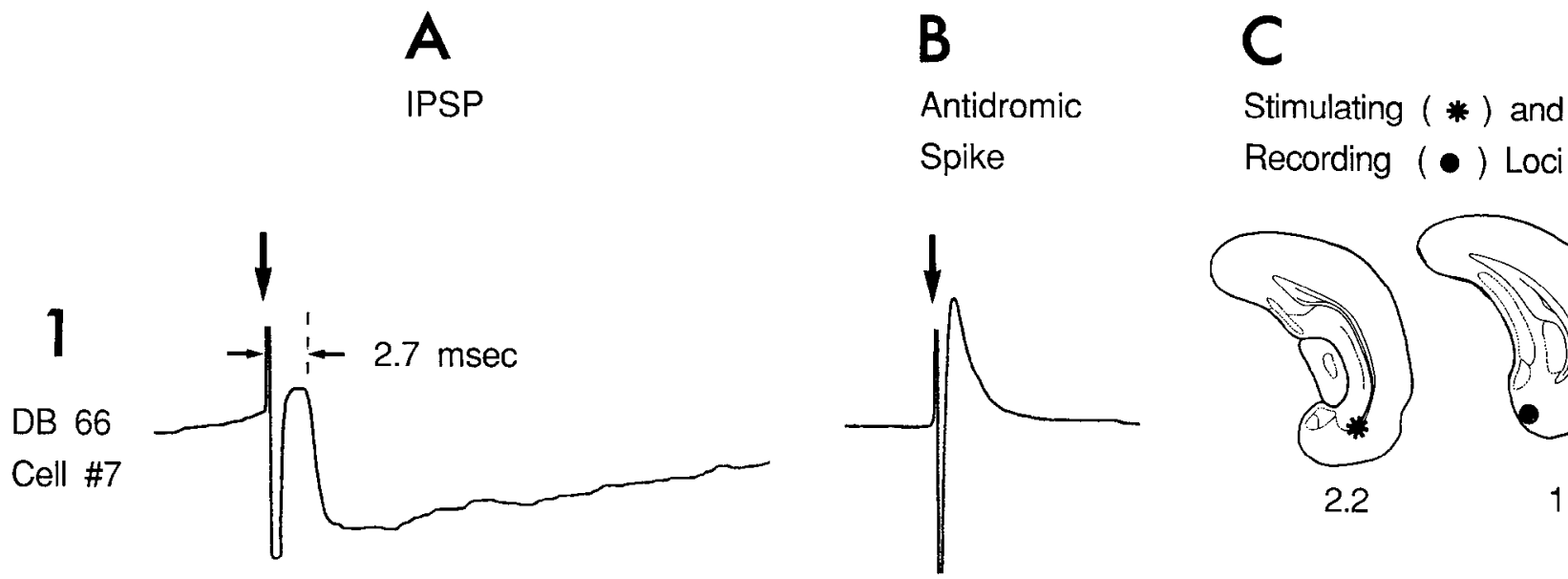

tential was mediated by a chloride current (Eccles, 1957; Kandel et al., 1961). KCl injections did not reveal the presence of shortcr-latency IPSP components.

Figure 7 shows the same lack of a consistent relationship between the latency of antidromic action potentials and IPSPs for 2 subicular complex neurons: both cells showed short-latency antidromic responses of about the same latency, 0.7 and 0.6 msec, in response to stimulation of the angular bundle and the CA3 field of the dorsal hippocampus, respectively. However, the IPSP in response to angular bundle stimulation showed a latency of only $5.3 \mathrm{msec}$, while the IPSP in response to CA3 stimulation was $16.9 \mathrm{msec}$. Again, this latter IPSP response latency is too long to be explained by the feedback model shown in Figure 1.

IPSPs were elicited by stimulation at more than one locus. Figure 8 shows electrode placements for 20 cells (in 8 different animals) in which inhibition was evoked by stimulation at 2 or 3 different sites. Nine of these cells (in 3 different animals) also

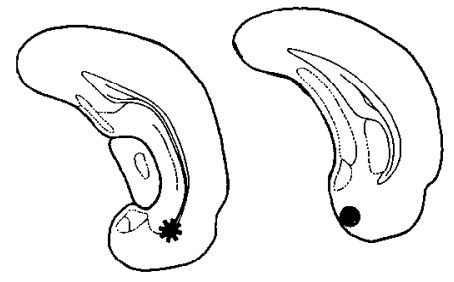

2.2

1.7
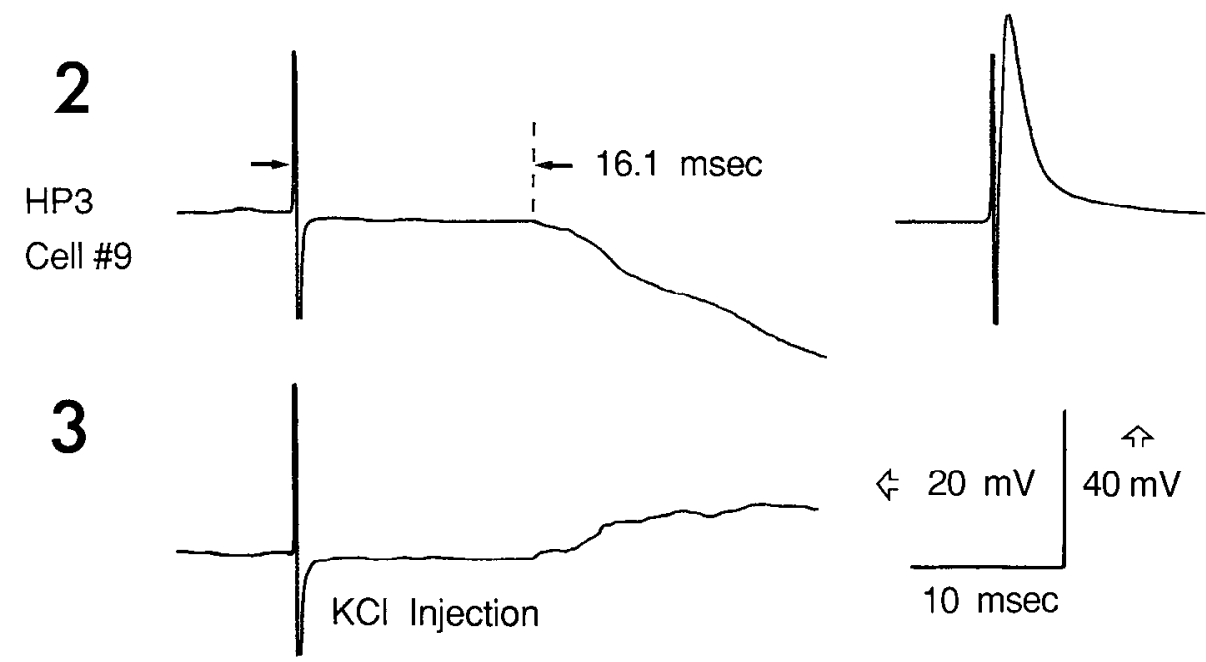

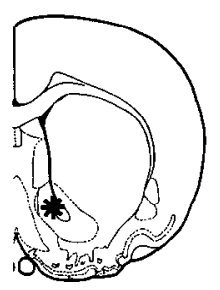

9.7

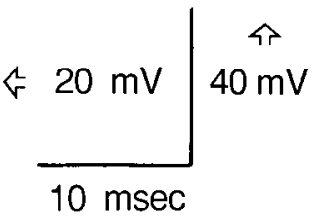

Figure 6. Latency relationships of antidromic spikes and IPSPs in 2 different entorhinal neurons. Both cells showed short-latency antidromic spikes $(B 1,2 ; 0.6$ and $0.5 \mathrm{msec}$ latencies, respectively). However, one of the cells showed a short latency IPSP $(2.7 \mathrm{msec} ; A)$; while the other cell showed a long latency IPSP $(16.1 \mathrm{msec} ; A 2,3)$. These latency relationships are not predicted by feedback inhibition. Stimulus intensity for DB66 was $200 \mu \mathrm{A}$; for HP3 $500 \mu \mathrm{A}$. The pipet for HP3 was filled with $3 \mathrm{M} \mathrm{KCl}$ : injection of $4.2 \mathrm{nA}$ of hyperpolarizing current (A3) inverted the IPSP, indicating its dependence on a chloride conductance. The pipet for DB66 was filled with $1 \mathrm{M} \mathrm{K}$ Citrate. Current clamp (negative current) of 0.7 , 1.7 , and $0.1 \mathrm{nA}$ was used for traces $A 1, B 1$, and $B 2$, respectively. Cell 7 , rat DB66, was from entorhinal layer II, and the stimulating electrode was in the angular bundle. Cell 9, rat HP3 was from entorhinal layer V, and the stimulating electrode was in the nucleus accumbens. 


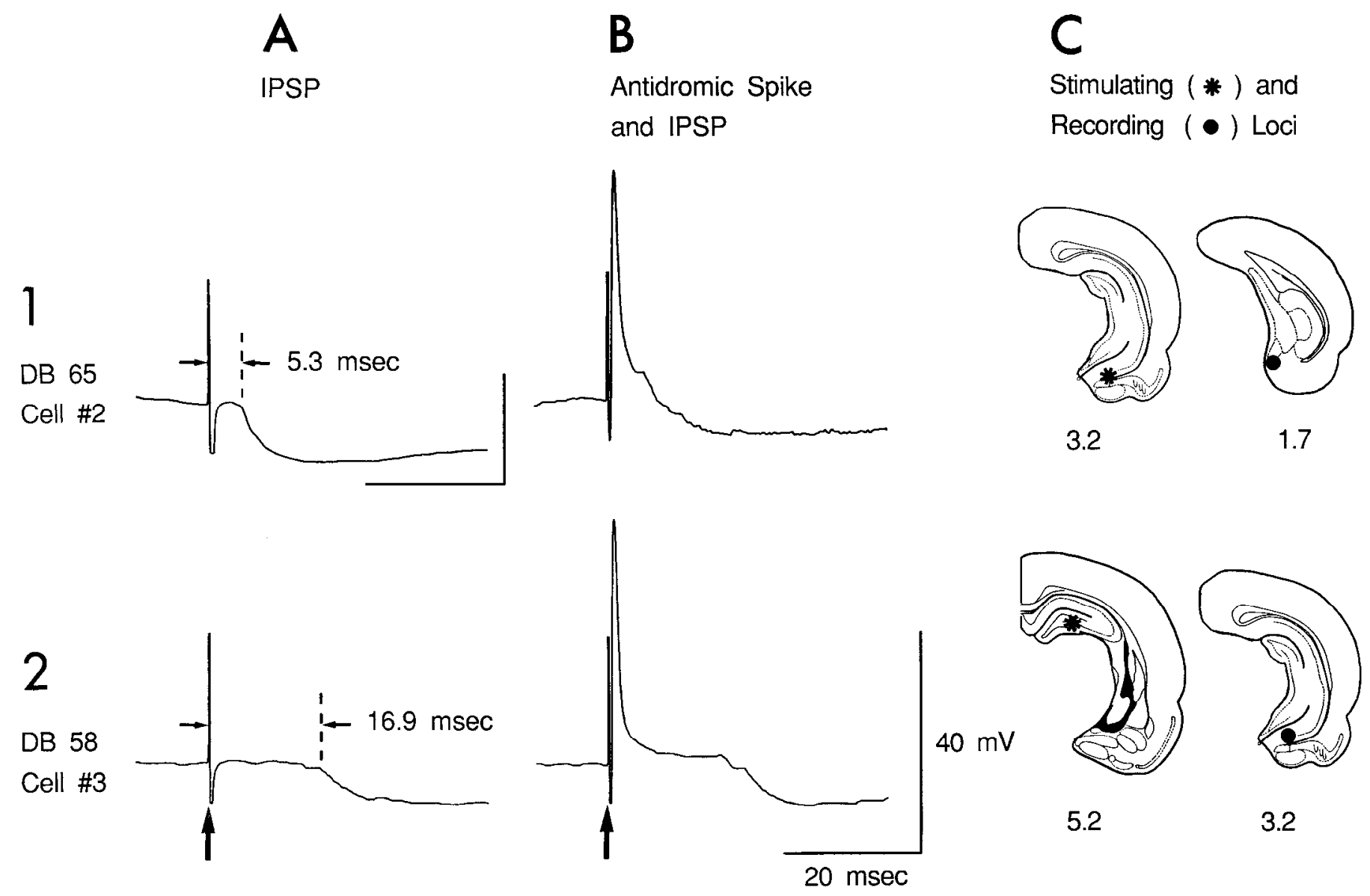

Figure 7. Latency relationships of antidromic spikes and IPSPs in 2 different subicular complex neurons. Similar to the entorhinal cells shown in Figure 6, both cells showed short-latency antidromic spikes $(B 1,2 ; 0.7$ and $0.6 \mathrm{msec}$ latencies, respectively). Also similar to Figure 6 , one of the cells showed a short latency IPSP $(5.3 \mathrm{msec} ; A 1, B 1)$, while the other cell showed a long latency IPSP (16.9 msec; $A 2, B 2)$, contrary to the prediction of a feedback model of inhibition. Stimulus intensity for DB65 was $500 \mu \mathrm{A}$; for DB58, 200 $\mu \mathrm{A}$. Current clamp (negative current) of 1.0 $\mathrm{nA}$ was used for trace $B 1$, which restored the capability of the cell to produce action potentials. Sweeps shown in $A 2$ and $B 2$ were collected near the threshold for the antidromic spike, so it was triggered intermittently (present in $B 2$, absent in $A 2$ ). Cell 2 , rat DB65 was from the parasubiculum, and the stimulating electrode was in the angular bundle. Cell 3, rat DB58 was from the subiculum proper, and the stimulating electrode was in the dorsal hippocampus, field CA3.

showed antidromic spikes to stimulation at 2 of the sites. This provided an opportunity to compare the latencies of antidromic spikes and IPSPs in the same cell when different pathways were activated. The mean difference in the antidromic latencies in response to stimulating 2 different sites was only $0.06 \pm 0.05$ $\mathrm{msec}(\mathrm{SD})$ in the 9 cells. That is, antidromic response latencies in response to stimulating 2 different loci were nearly identical. The mean difference in the IPSP latencies was much larger: $14.7 \pm 15.7 \mathrm{msec}$. Thus, for each of the 9 cells considered individually, there was a negligible difference in the antidromic spike latencies when stimulating 2 different sites but considerable difference in the IPSP latencies. This is not predicted by the feedback model of inhibition. Under this model, and assuming that the recordings were representative of the population of cells from which they were drawn, the IPSP latencies obtained by stimulating 2 different sites should have been nearly identical, since the antidromic latencies were nearly identical. Figure 9 presents data from 1 of the 9 cells. Shown are the IPSPs to diagonal band $(A 1, C l)$ and $\mathrm{CA} 3(A 2, C 2)$ stimulation; and the antidromic spikes $(B 1, B 2)$. The latencies of the antidromic spikes to diagonal band and CA3 stimulation in this cell were identical $-0.6 \mathrm{msec}-$ while the IPSP latencies differed by almost
9 msec (column C). This suggests that the IPSPs were not initiated by antidromic activation of an inhibitory circuit.

In distinction to the lack of a consistent relationship between the latency of antidromic action potentials and IPSPs, there was a close temporal association of EPSPs and IPSPs: short-latency EPSPs were associated with short-latency IPSPs, and long-latency EPSPs were associated with long-latency IPSPs. A neuronal record of this close temporal association of evoked EPSPs and IPSPs is presented in Figure 10, which shows the average response of a layer II entorhinal neuron to hippocampal field CA4 stimulation. The difference in latency between the EPSP and IPSP in this cell was $1.1 \mathrm{msec}$. For all of the layer II entorhinal cells that showed both an EPSP and an IPSP in response to stimulation of the hippocampus ( $n=5$, out of 14 cells tested), the mean of the latency differences between EPSPs and IPSPs was $2.8 \mathrm{msec}$. As for the cell shown in Figure 10, EPSPs often appeared to be shortened by subsequent IPSPs. With regard to the subicular complex, stimulation of the hippocampus and related structures (dentate gyrus or fimbria) evoked both EPSPs and IPSPs in 6 subicular complex neurons (of 18 tested). The mean of the latency differences between the EPSPs and IPSPs was $5.4 \mathrm{msec}$. These mean latency differences between hippo- 

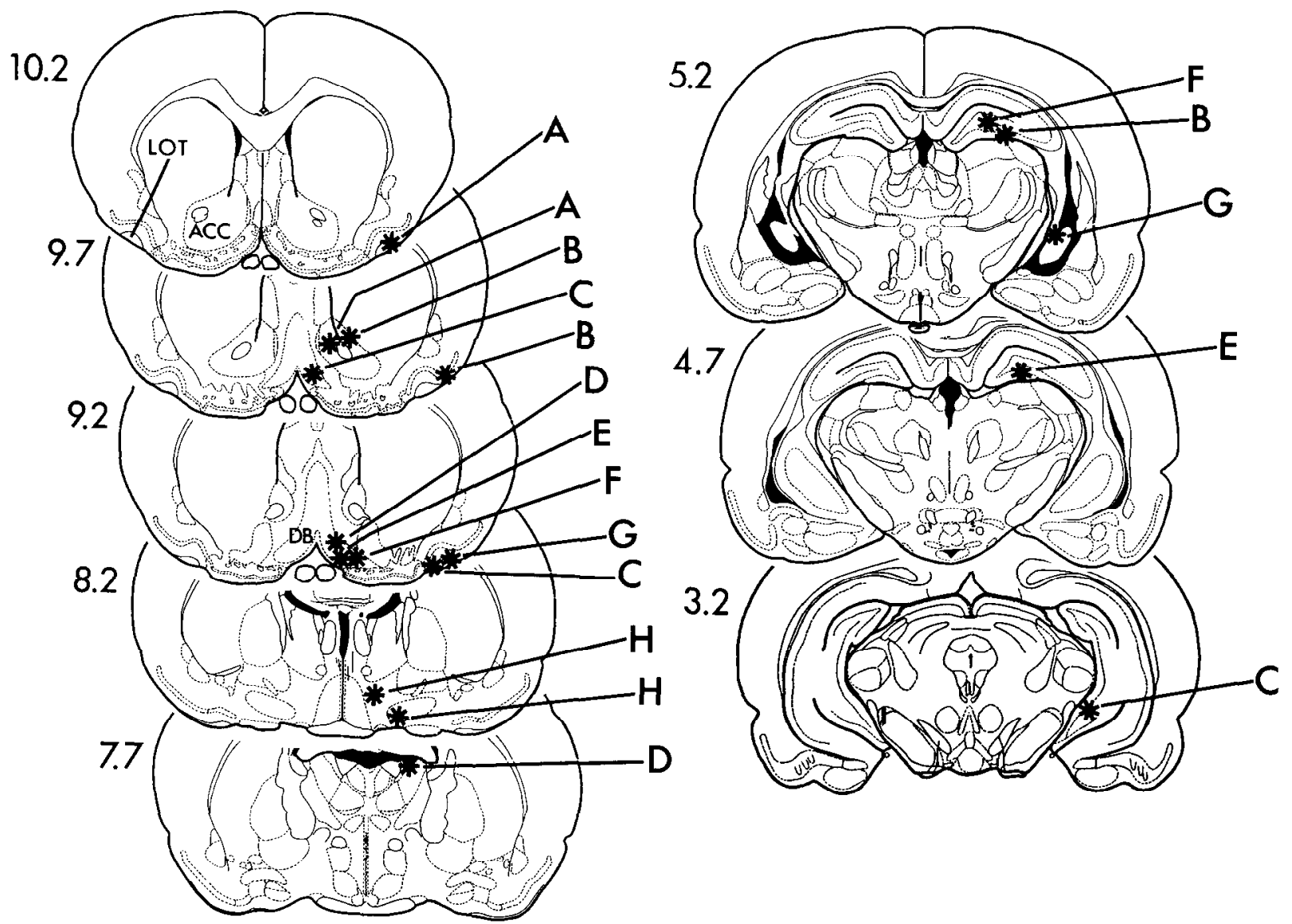

3.2

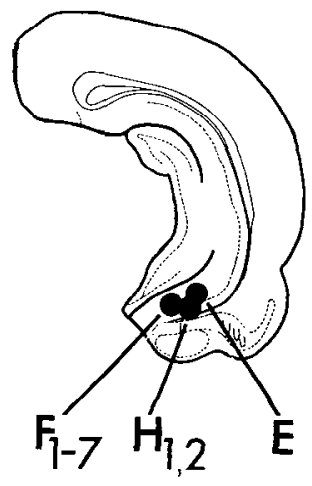

2.7

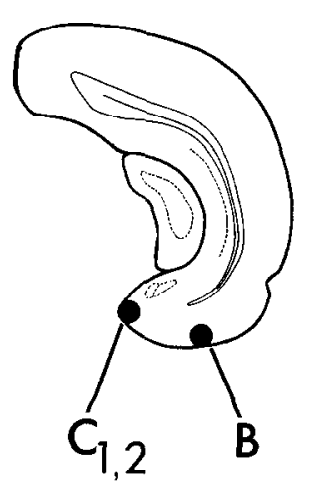

2.2

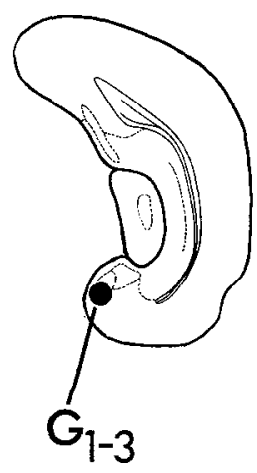

1.7

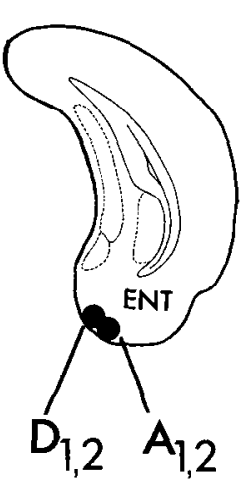

Figure 8. Stimulating and recording loci for cells that responded with an IPSP to stimulation at 2 different sites $(A, D-H)$ or 3 different sites $(B$, C). Letter pairs indicate corresponding stimulating (asterisks, above) and recording ( filled circles, below) loci for the same cell. Subscripts indicate multiple cells activated by the same stimulating sites. Frontal sections are based on the atlas of Paxinos and Watson (1982), and numbers next to the sections indicate millimeters anterior to the interaural line.

campus-evoked EPSPs and IPSPs (2.8 and $5.4 \mathrm{msec}$ for layer II entorhinal and subicular complex neurons, respectively) show good agreement with the value of $4.5 \mathrm{msec}$ predicted for the model of feedforward inhibition in which excitatory afferents activate both inhibitory and principal neurons (see Neuronal circuit models, above, and Fig. 2). Stimulation of the lateral olfactory tract and surrounding olfactory cortex also evoked EPSP-IPSP sequences in layer II entorhinal principal neurons, in 4 cells (out of 16 tested). The EPSP-IPSP latency difference for one of the cells was $4.6 \mathrm{msec}$ (with EPSP and IPSP latencies of 12.4 and $17.0 \mathrm{msec}$, respectively), which is in excellent agreement with the feedforward model prediction of $4.5 \mathrm{msec}$ (Fig. 2). The 3 other cells showed longer than predicted EPSP-IPSP latency differences (of 9.8, 10.1 and $15.9 \mathrm{msec}$ ). Some of this discrepancy may reflect propagation delays in local axonal projections of inhibitory neurons (see Discussion) or more complex circuitry involving synaptic relays that could prolong EPSP duration.

Stimulation of the nucleus of the diagonal band of Broca (DBB) reliably evoked antidromic spikes and IPSPs but not 

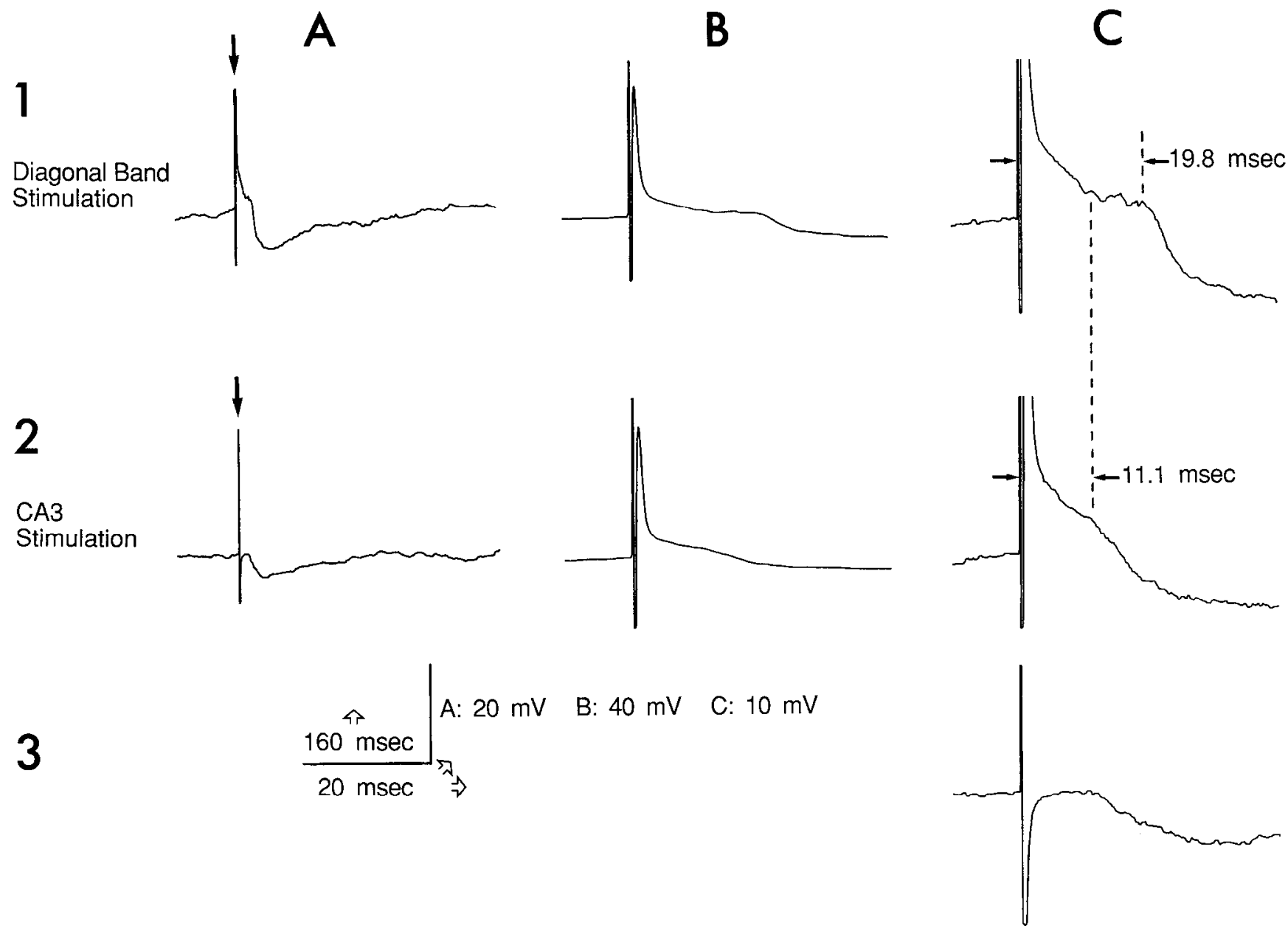

Figure 9. Records showing the lack of a consistent relationship between antidromic spike latencies and IPSPs in the same cell. All traces are from the same subicular principal cell (rat DB58, cell 7) and show responses to stimulation at 2 different loci (rows 1 and 2). Vertical arrows point to the stimulus artifact. $A$, IPSPs at a low time resolution; $B$, antidromic spikes (both had a latency of $0.6 \mathrm{msec}$ ); and $C$, IPSPs at a high resolution (spikes truncated). Trace $C 3$ shows the response to $\mathrm{CA} 3$ stimulation for a sweep in which the antidromic spike was not triggered. Stimulus intensity for all traces was $300 \mu \mathrm{A}$. The $160 \mathrm{msec}$ calibration bar applies to $A$, the $20 \mathrm{msec}$ bar to $B$ and $C$. Note the different IPSP latencies in $C 1$ and $C 2$, even though the antidromic spike latencies were identical.

EPSPs. Therefore, the source of the inhibitory responses is not clear. For example, DBB stimulation (Table 2) evoked IPSPs in $59 \%$ of the subicular complex neurons (10/17), and antidromic responses in $76 \%(13 / 17)$. The average antidromic spike latency $(0.7 \mathrm{msec})$ was too short to account for the average IPSP latencies (11.6 msec) under a feedback inhibitory circuit, which would predict an IPSP latency of $6.7 \mathrm{msec}$ (i.e., $6 \mathrm{msec}$ longer than the antidromic spike latency of $0.7 \mathrm{msec}$ ). However, since none of the subicular complex cells showed EPSPs, the circuitry of Figure 2 is unlikely. It is possible that the diagonal band is excitatory but only to local or distant inhibitory neurons that contact subicular principal cells (feedforward circuit of Fig. 1). It is also possible that a cholinergic projection from the diagonal band could have direct inhibitory effects (direct inhibition of Fig. 1), since ACh has been shown to hyperpolarize central neurons of the nucleus parabrachialis (Egan and North, 1986).

The IPSP morphology in 5 cells is worthy of mention, in that they were biphasic. During the recovery phase, IPSPs in these cells had an early fast component and a later slower component. Figure 11 shows an example in a layer II entorhinal neuron. The recovery phase showed an inflection point (Fig. $11 \mathrm{~B}$, curved arrow), suggesting that 2 separate mechanisms contributed to the IPSP. These may correspond to the activation of chloridemediated responses of $G A B A_{A}$ receptors and longer potassiummediated responses of $\mathrm{GABA}_{\mathrm{B}}$ receptors that have been reported in the rat hippocampus (Nicoll and Newberry, 1984) and in turtle neocortex (Kriegstein and Connors, 1986), though further study is necessary to establish this.

\section{Correlation analysis of responses}

The antidromic spike-IPSP and EPSP-IPSP latency relationships were analyzed more quantitatively by performing a correlation analysis. For this purpose, latency data from the present study were combined with latency data from one of our previous studies (Finch et al., 1986a), in order to provide more data points for entorhinal cells in response to stimulation of the hippocampal formation (hippocampus proper, dentate gyrus, and subicular complex). Subicular complex or entorhinal principal cells showing both an antidromic spike and an IPSP were selected from this combined data set. All stimulating loci were pooled in the analysis, since 10 of the 13 stimulating-recording combinations evoked antidromic action potentials in at least $40 \%$ of the cells from which data were obtained, sufficient to expect population effects from antidromic activation of a feedback cir- 


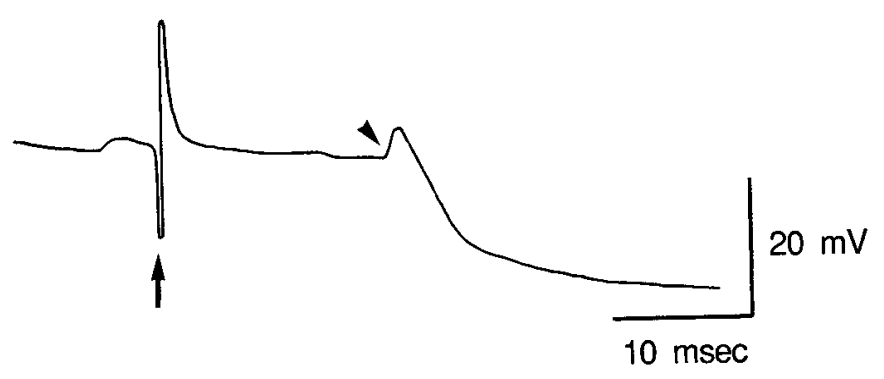

Figure 10. Trace showing the close temporal relationship between EPSPs and IPSPs. This trace shows the average response of a layer II entorhinal principal cell to 12 stimulus pulses applied to CA4 $(500 \mu \mathrm{A}$ intensity). Arrow points to stimulus artifact, arrowhead to EPSP. Rat DG7, cell 1 .

cuit. A total of $76 \%$ of the tests of entorhinal cells $(39 / 51)$ and $43 \%$ of the tests of subicular complex cells $(51 / 118)$ showed antidromic activation. (Some cells were tested for responses at more than one stimulating locus, so the results are expressed in terms of number of tests rather than number of cells.) These percentages of responsive cells are high enough to expect significant population effects if a feedback circuit were present. Correlation coefficients were computed from the data, using as input the antidromic and IPSP latencies for each cell that showed both responses.

Next, subicular complex or entorhinal principal cells showing both an EPSP and an IPSP were selected. Only 2 afferent systems reliably evoked EPSPs (Table 2): the LOT (including also the primary olfactory cortex and the olfactory tubercle) and the hippocampus (HPC; including also the dentate gyrus and, with respect to entorhinal afferents, the subicular complex). Thereforc, thesc sites werc analyzed separately. The angular bundle (AB) stimulating sites were included with the $\mathrm{HPC}$, since $\mathrm{AB}$ is the white matter immediately adjacent to the subicular complex and entorhinal cortex through which afferents from the HPC enter these structures. This provided short-latency data and increased the range of EPSP latencies to be analyzed. A total of $26 \%$ of the tests of entorhinal cells $(5 / 19)$ and $0 \%$ of the tests of subicular complex cells $(0 / 12)$ showed EPSPs in response to LOT stimulation; and $34 \%$ of the tests of entorhinal cells (26/ 76 ) and $72 \%$ of the tests of subicular cells (13/18) showed EPSPs in response to HPC stimulation. These percentages of responsive cells (excepting LOT to subicular complex) are high enough to expect significant population effects if a feedforward circuit were present. As above, correlation coefficients were computed, using as input the EPSP and IPSP latencies for each cell that showed both responses.

The antidromic-IPSP latency correlations were not significant, indicating no relationship between these variables $(R=$ $0.09, p>0.65, n=29$ for entorhinal cells; $R=0.023, p>$ $0.92, n=24$ for subicular complex cells). By contrast, the EPSPIPSP correlations for HPC stimulation were highly significant, indicating a strong relationship between EPSP and IPSP latencies in response to stimulation of the dentate gyrus, $\mathrm{HPC}$, and $\mathrm{AB}(R=0.75, p<0.001, n=20$ for entorhinal cells; $R=0.84$, $p<0.008, n=8$ for subicular complex cells). The EPSP-IPSP latency correlation for LOT stimulation (only entorhinal cells showed EPSPs) was not significant ( $R=0.62, p<0.27, n=$ $5)$, probably reflecting the low range of EPSP latencies evoked by LOT stimulation: The range of EPSP latencies for LOT stimulation was only $9.2 \mathrm{msec}(6.5-15.9 \mathrm{msec}$ in different cells),
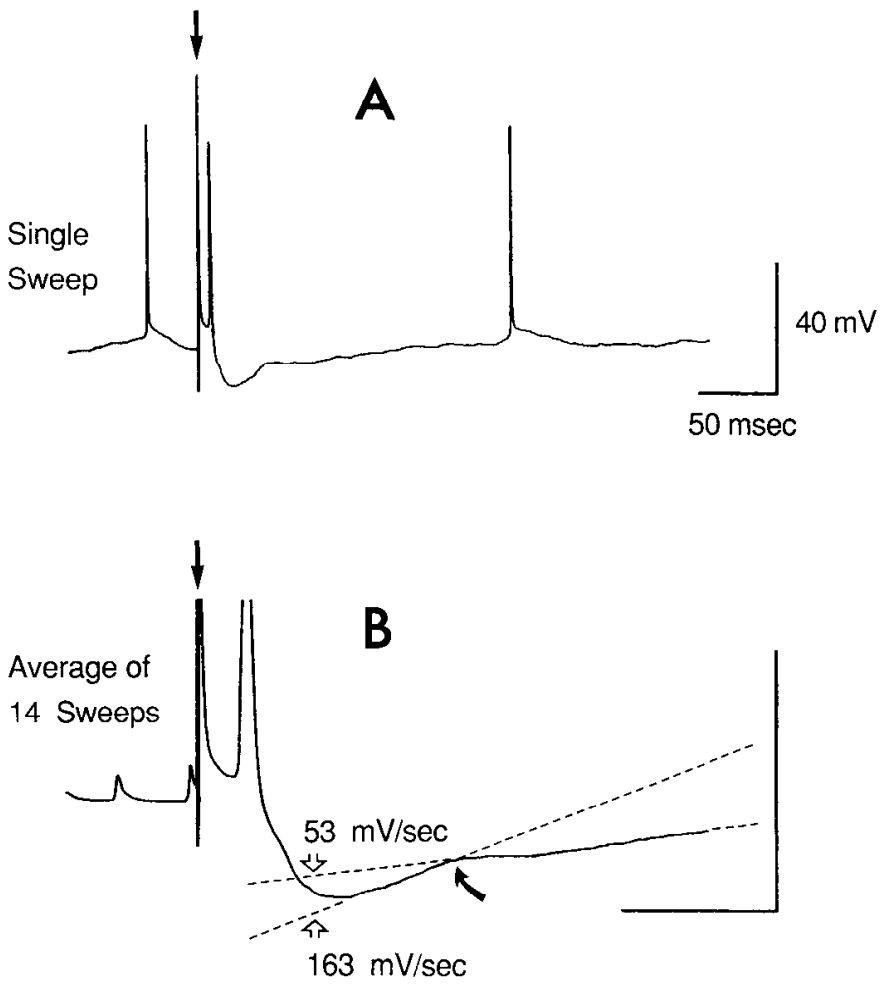

Figure 11. Example of an IPSP with biphasic recovery. Both traces are from the same layer II entorhinal neuron and show the response to $\mathrm{CA} 2$ stimulation $(500 \mu \mathrm{A}$ intensity, straight arrows point to stimulus artifact). Curved arrow in $B$ indicates the inflection point during recovery, and the slopes of the 2 components are also indicated. These results suggest that 2 distinct mechanisms may contribute to the IPSPs of some cells.

while the range of latencies for HPC stimulation was $19.4 \mathrm{msec}$ (2.5-21.9 msec) in entorhinal cells and $12 \mathrm{msec}$ in subicular complex cells $(5-17 \mathrm{msec})$.

The correlation analyses were also performed on pooled data (Fig. 12). These coefficients were obtained by selecting data from all principal cells that showed both an antidromic spike and an IPSP (Fig. 12A), regardless of stimulating locus or recording site, and all principal cells that showed both an EPSP and an IPSP, again regardless of stimulating locus or recording site (Fig. $12 B)$. As before, and as shown in Figure 12, the antidromicIPSP correlation $(n=53)$ was not significant $(R=0.03, p>$ $0.82)$, while the EPSP-IPSP correlation $(n=36)$ was highly significant $(R=0.73, p<0.0001) . R^{2}$ is a measure of the proportion of variance accounted for by the regression line (Alder and Roessler, 1964). Therefore, the correlation analysis indicates that over half (53\%) of the variance in IPSP latencies in this study can be accounted for by the linear relation between EPSP and IPSP latencies. The correlation between antidromic spike latencies and IPSP latencies was not significant, so antidromic spike latencies account for none of the EPSP latency variance. Accordingly, knowledge of the antidromic spike latency gives no information about IPSP latency, while knowledge of the EPSP latency allows a strong prediction to be made about the IPSP latency.

The $y$ intercept for the EPSP-IPSP latency correlation of Figure $12 B$ was $6.8 \mathrm{msec}$. This is the experimentally derived estimate of the time delay between EPSPs and IPSPs in principal neurons. This estimate is in reasonably good agreement with the value of 4.5 msec predicted by the feedforward model of 

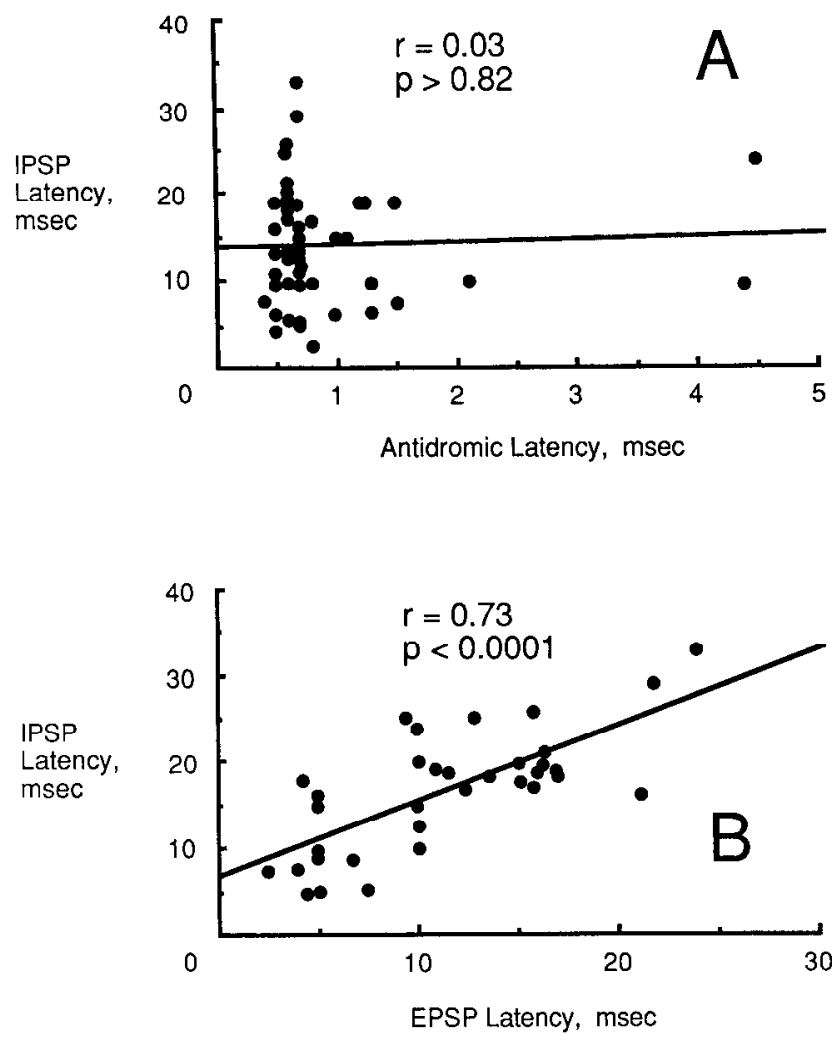

Figure 12. Correlation analysis of response latencies. All stimulatingrecording pairs that showed both an antidromic spike and an IPSP $(A)$ or both an EPSP and an IPSP $(B)$ were used as inputs to the analysis. Data from this series of experiments and from the serics in Finch et al. (1986a) were used. The least-square regression lines were fit by computer. Note the lack of correlation between antidromic and IPSP latencies, and the highly significant correlation between EPSP and IPSP latencies.

inhibition shown in Figure 2. The correlation analysis thus provides no clear support for the antidromic activation of a feedback inhibitory circuit within the entorhinal cortex and subicular complex but does provide support for feedforward inhibition.

\section{Candidate inhibitory neurons}

The feedforward model of inhibition requires the local presence of inhibitory neurons. We encountered 2 candidate inhibitory neurons in this series of recordings (out of 64 cells). One of the cells (rat HP7, cell 5) was located in layer III of the entorhinal cortex and was activated by stimulation of the lateral olfactory tract; the other (rat DB1 7, cell 2) was located in the parasubiculum and was activated by stimulation of the fimbria. The cells were classified as candidate inhibitory neurons by their response to stimulation: both cells showed a burst of action potentials (Figs. 13, 14), which is considered to be a response characteristic of candidate inhibitory neurons (Andersen, 1975). This is in marked contrast to the recordings from all of the other cells in this study, which never showed more than one evoked action potential. Both of the candidate inhibitory neurons had short duration action potentials ( 0.6 and $0.4 \mathrm{msec}$ for the parasubicular and entorhinal neuron, respectively), which is also a feature of candidate inhibitory neurons (Knowles and Schwartzkroin, 1981).

Another requirement for feedforward inhibition is that the population of candidate inhibitory neurons must have excitatory response latencies shorter than the inhibitory response

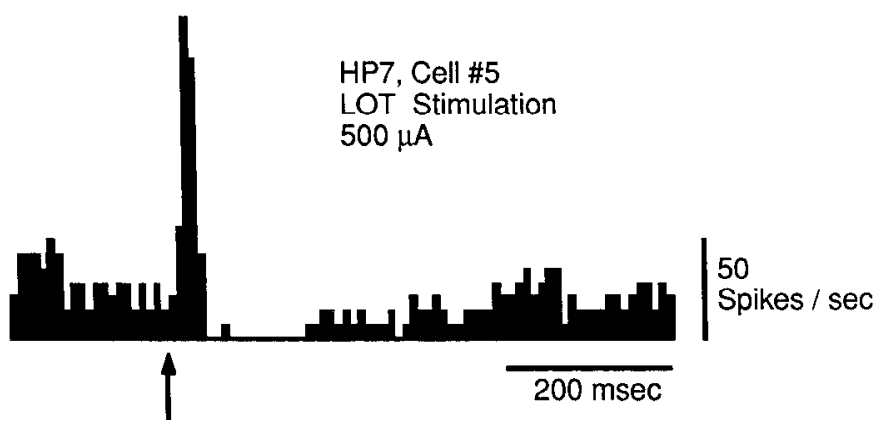

Figure 13. Peristimulus time histogram from a candidate inhibitory neuron. Arrow indicates the time of stimulation. Histogram is based on 16 stimulus presentations, and the bin width is $9.1 \mathrm{msec}$.

latencies of principal cells. The latency difference must be large enough to account for the propagation of action potentials from the inhibitory neurons to their terminals on principal neurons and for synaptic delay. In order to evaluate these latency relationships, we obtained recordings from principal cells in the same electrode track as the candidate inhibitory neurons and activated them with the same stimulus parameters used to activate the candidate inhibitory ncurons. Table 3 shows the evoked spike latencies from the 2 candidate inhibitory neurons in this study and similar data from 3 candidate inhibitory neurons recorded in our previous studies (Finch and Babb, 1980b; Finch et al., 1986a). These represent all cases obtained to date in which latency data for candidate inhibitory neurons were obtained along with latency data for nearby principal cells. From Table 3 , the average latency difference between evoked spikes in these 5 candidate inhibitory neurons and IPSPs in nearby principal neurons is $3.3 \mathrm{msec}$, in good agreement with the predicted 1.5 msec (see Neuronal circuit models). By contrast, given the short latency of the average principal cell antidromic responses, the excitatory response latencies in the candidate inhibitory neurons were too long to be accounted for by antidromic activation of a recurrent inhibitory circuit.

Figure 14 shows these latency relationships for one candidate inhibitory ncuron of the present study (rat DB17, cell 2) and for a nearby principal neuron (cell 3 ). The 2 cells were both in the parasubiculum, within about $0.8 \mathrm{~mm}$ of each other. The candidate inhibitory neuron showed an average EPSP latency of $7.5 \mathrm{msec}$ in response to fimbria stimulation. The average orthodromic spike latency was $10.4 \mathrm{msec}$ (Fig. 14, measured from the stimulus artifact to the start of the orthodromic spike). The difference, $2.9 \mathrm{msec}$, represents the average rise time of the EPSP to the threshold for spike initiation. Using the same stimulus parameters, the nearby principal cell showed an average IPSP latency of $16.0 \mathrm{msec}$. Therefore, the average time from the inhibitory cell orthodromic spike to the principal cell IPSP was $5.6 \mathrm{msec}$ (Table 3; the value for the sweep shown in Fig. 14 was $5.7 \mathrm{msec}$ ). This is considerably longer than the assumed value of $1.5 \mathrm{msec}$ but is only $2 \mathrm{msec}$ longer than the value of $3.6 \mathrm{msec}$ for a simultaneously recorded cell pair in hippocampal field $\mathrm{CA} 3$ found by Miles and Wong (see Discussion). Note the reciprocal firing relationship of these 2 cells. The principal neuron stopped firing during the excitatory burst of the candidate inhibitory neuron and began to fire at the termination of the burst. This is consistent with the feedforward model, in which inhibitory neurons receive excitation from extrinsic afferents, rather than from nearby principal neurons. 
Interestingly, this candidate inhibitory cell also showed a shortlatency antidromic response to fimbria and diagonal band stimulation. The latency to fimbria stimulation, $0.8 \mathrm{msec}$, corresponded to an axonal conduction velocity of $14.8 \mathrm{~m} / \mathrm{sec}$. This indicates that at least some of the candidate inhibitory neurons are projection neurons and that they may provide inhibition to distant, as well as to local, neurons.

\section{Discussion}

These results provide evidence that the prominent inhibitory responses of entorhinal cortex and subicular complex principal neurons are produced by activation of a feedforward inhibitory circuit. In this proposed circuit, excitatory afferent fibers activate entorhinal and subicular complex inhibitory neurons, which in turn inhibit the principal cells. The afferent fibers may also directly excite the principal cells.

Sevcral of our experimental findings support these conclusions. (1) Candidate inhibitory neurons were present near inhibited principal neurons. The candidate in hibitory neurons had many of the same physiological characteristics and response properties as candidate inhibitory neurons in the hippocampus (Andersen, 1975; Finch and Babb, 1977; Schwartzkroin and Mathers, 1978). (2) Inhibitory responses in the principal cells had the latency relationships with excitatory responses in the candidate inhibitory neurons that are necessary for feedforward inhibition. Specifically, as a group, the principal cell IPSPs showed latencies that were consistent with direct input from candidate inhibitory cells (Table 3). (3) Principal cell EPSP and IPSP latencies were highly correlated (Fig. 12B). This is predicted by the feedforward circuit model shown in Figure 2, in which excitatory afferents activate both principal cells and inhibitory cells. The correlation analysis indicated an average delay of 6.8 msec from the start of principal cell EPSPs to the start of principal cell IPSPs, in good agreement with the $4.5 \mathrm{msec}$ model prediction. And (4), latency relationships of antidromically elicited action potentials and IPSPs were not consistent with antidromic activation of a feedback inhibitory circuit (Fig. 12A).

We present data here in which there is a far greater time between principal cell antidromic spikes and principal cell IPSPs than the $6 \mathrm{msec}$ predicted by feedback inhibition. For example, for hippocampal stimulation and subicular complex recording, the antidromic spike latencies in principal cells averaged only $0.6 \mathrm{msec}$, while the IPSP latencies averaged $18.7 \mathrm{msec}$ (Table

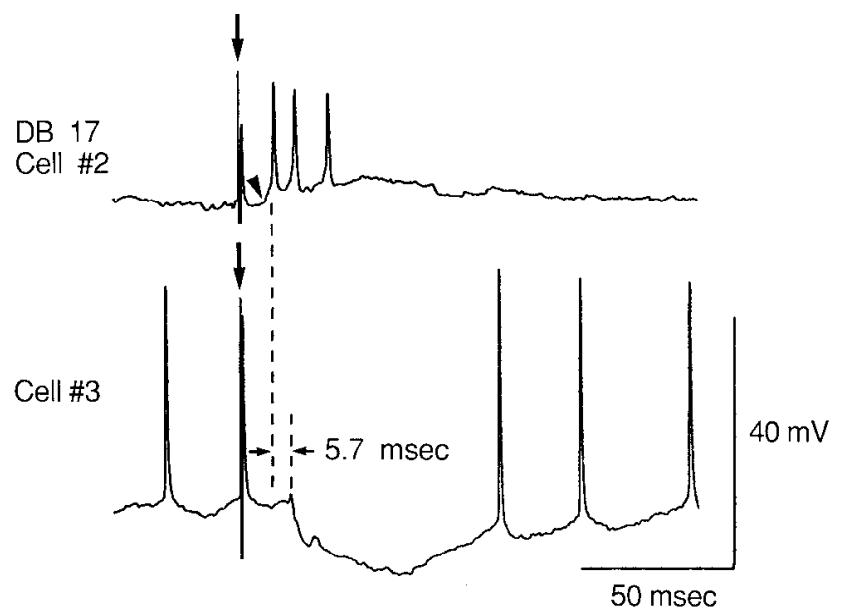

Figure 14. Recording from a candidate inhibitory neuron (cell 2) and from a nearby principal neuron (cell 3). Both cells were recorded in the same electrode track; both were located in the parasubiculum; and both were activated with $6.6 / \mathrm{sec}$ fimbria stimulation (vertical arrows) at an intensity of $500 \mu \mathrm{A}$. Arrowhead in the top trace indicates onset of the EPSP. The time delay from the onset of the EPSP-triggered action potential in the candidate inhibitory neuron to the onset of the IPSP in the principal neuron was $5.7 \mathrm{msec}$. Note the reciprocal firing pattern of the 2 cells.

2). This latency difference is too great to be explained by antidromic action of a feedback inhibitory circuit. The correlation analysis of antidromic spike and IPSP latencies (Fig. 12A) showed more systematically that there was no relationship between the latencies of antidromic spikes and IPSPs. This strongly suggests that antidromic spikes did not participate in the inhibition we observed. Accordingly, it is appropriate that we not accept, on the basis of these data, a feedback model in which antidromic activation of principal neurons can initiate inhibition.

We found significant variability in latency relationships across cells. However, this degree of variability is entirely consistent with that found across different simultaneously recorded cell pairs in the CA3 hippocampal slice preparation, in which there was evidence for monosynaptic coupling (Miles and Wong, 1984). Differences in action potential propagation times along local circuit pathways would contribute to the observed variability in latency relationships (e.g., Fig. 12B, Table 3). These delays cannot be directly observed but are dependent in part upon the

Table 3. Latency relationships of candidate inhibitory neurons and nearby principal cells

\begin{tabular}{llllllc} 
Rat & Cell & Cell locus & $\begin{array}{l}\text { Stimulation } \\
\text { site }\end{array}$ & $\begin{array}{l}\text { Spike } \\
\text { latency } \\
\text { (msec) }\end{array}$ & $\begin{array}{l}\text { IPSP latency } \\
\text { of nearby } \\
\text { principal } \\
\text { cells (msec) }\end{array}$ & $\begin{array}{l}\text { Latency dif- } \\
\text { ference (msec) }\end{array}$ \\
\hline DB17 & 2 & Parasub & Fimbria & 10.4 & 16.0 & 5.6 \\
EN67 & 6 & Sub & Presub & 6.8 & 11.0 & 4.2 \\
EN67 & 6 & Sub & aco & 8.5 & 12.2 & 3.7 \\
HE56 & 1 & Ent, II-III & Fimbria & 15.9 & 19.4 & 3.5 \\
HP7 & 5 & Ent, III & LOT & 13.7 & 13.2 & -0.5 \\
Average & & & & & & 3.3
\end{tabular}

Entries show orthodromic spike latencies of candidate inhibitury cells and IPSP latencies of principal cells recorded in the same structure and electrode track. Note that EN67, cell 6 was excited by stimulation at 2 different placements. Principal cell IPSP latencies were averaged when more than one cell was recorded from. DB17 and HP7 are from this series of experiments; HE56 is from the series in Finch and Babb (1980a); and EN67 is from the scrics in Finch ct al. (1986a, b). Abbreviations: aco, cortical nucleus of the amygdala; LOT, lateral olfactory tract; Parasub, parasubiculum; Presub., presubiculum; Sub, subiculum. 
local axonal lengths and diameters. We assume an average value of $0.5 \mathrm{msec}$ for propagation of action potentials in local circuits, allowing time for conduction along small, unmyelinated local axonal domains. This seems reasonable in light of the extremely small-diameter inhibitory cell axonal segments that have becn reported within hippocampal field CA1. Using electron microscopy, Schwartzkroin and Kunkel (1985) found that candidate inhibitory CA1 cells showed axonal segments with diameters as small as $0.06 \mu \mathrm{m}$. These segments would support only very slow conduction velocities, about $0.1 \mathrm{~m} / \mathrm{sec}$ (extrapolated from data in Ruch et al., 1965). Similar small-diameter axonal segments are likely to be present in inhibitory neurons of the entorhinal cortex and subicular complex. Variations in axonal length between inhibitory and principal cclls could thus result in considerable latency differences between inhibitory cell EPSPs and principal cell IPSPs for different cell pairs.

Anatomical support for the interpretation of feedforward inhibition is necessary. A basic anatomical requirement is that the structures that we stimulated actually project to the entorhinal cortex and subicular cortex. This is true for the HPC, AB, subicular complex (with reference to subiculo-entorhinal interactions), olfactory cortex, LOT, and diagonal band, all of which have been shown to project to the entorhinal cortex and/or subicular complex (e.g., Shipley, 1974; Swanson and Cowan, 1977; Beckstead, 1978; Finch et al., 1983; Wouterlood and Nederlof, 1983; Alonso and Köhler, 1984; Room et al., 1984; Köhler, 1985).

An additional anatomical requirement for feedforward inhibition is that afferent fibers make a direct, excitatory synapse on inhibitory neurons. This requires more detailed study and has so far been demonstrated only for afferents of the olfactory system, which project via the LOT. Wouterlood et al. (1985) have used combined immunocytochemistry and electron microscopy to show that olfactory bulb afferents to the entorhinal cortex synapse directly on entorhinal inhibitory neurons (GADpositive neurons). The synapses were asymmetric, which is often considered to be an indication of excitatory synapses. These workers have also shown that the olfactory afferents terminate on layer II and III entorhinal principal neurons (Wouterlood and Nederlof, 1983). Together, these studies provide anatomical support for the feedforward model shown in Figure 2. Our mod$\mathrm{el}$, based on physiological data, is identical to theirs (shown in fig. 15 of Wouterlood et al., 1985).

There is no requirement that the feedforward inhibitory circuits be activated monosynaptically. It is likely that some of the responses were oligosynaptic, for example, responses to dentate stimulation, with a probable relay in the hippocampus (see Finch et al., 1986a). However, even some of the long-latency responses could have reflected monosynaptic activation. The clearest case for this can be made for responses of layer II entorhinal neurons to LOT stimulation. As discussed above, there is anatomical evidence for direct projections of the LOT to layer II of the entorhinal cortex. But the average excitatory response latency was long-11.9 msec (Table 2). Kerr and Dennis (1972) have shown that caudally directed collaterals of cat lateral olfactory tract fibers conduct very slowly, at about $0.8 \mathrm{~m} / \mathrm{sec}$. The distance between LOT stimulation loci and the entorhinal recording sites in the present study was about $10 \mathrm{~mm}$. Assuming a conduction velocity of $0.8 \mathrm{~m} / \mathrm{sec}$ for these fibers in the rat, the expected monosynaptic response latency is about $13.5 \mathrm{msec}(12.5 \mathrm{msec}$ for propagation plus $1 \mathrm{msec}$ for synaptic delay), in good agreement with the experimentally obtained average of $11.9 \mathrm{msec}$.
Single principal cells could show inhibition in response to stimulation of more than one structure (Fig. 8), indicating that inhibitory influences converge onto the same cell. In one case, a candidate inhibitory neuron was excited by stimulation of more than one structure (Tablc 3, EN67 cell 6). This suggests that the convergent inhibitory influences onto entorhinal principal cells might be mediated at the level of single inhibitory neurons. This physiological evidence is again consistent with the anatomical work of Wouterlood et al. (1985), who found both degenerating (olfactory) and nondegenerating (presumably nonolfactory) asymmetric synaptic terminals on the same entorhinal inhibitory neuron.

No evidence for feedback inhibition was obtained in this study, but its prescnce cannot be rulcd out. Local axonal collaterals from a variety of entorhinal cell types are present within the entorhinal cortex (I orenté de No, 1933), and these could provide the substrate for feedback circuitry. It is possible that feedback inhibition in the present study was too weak to be detected; that much higher stimulus intensities are necessary in order to produce it; or that it cannot be readily activated by antidromic stimulation. Suprathreshold stimulus intensities were used in this study, but it is possible that even higher stimulus intensities would have provided evidence for feedback inhibition. It is also possible that feedback inhibition cannot always be readily initiated by antidromically propagated action potentials: Hyperpolarization can block antidromic somatic invasion of action potentials at the initial segment (Eccles, 1957). Sufficient tonic, synaptically induced hyperpolarization could conceivably block antidromic activation further from the soma, at local axonal collaterals, thereby interfering with antidromically activated recurrent inhibition.

It is also not possible to rule out a contribution to some of the IPSPs via direct inhibition (Fig. 1). Recent studies have shown that limbic system nonpyramidal neurons (some of which are candidate inhibitory neurons) and immunocytochemically defined GABAergic neurons (putative inhibitory neurons) have efferent axonal projections, in addition to local projections (Alonso and Köhler, 1982; Seress and Ribak, 1983; Babb et al., 1986; Schwerdtfeger and Buhl, 1986). Such direct inhibitory projections to the entorhinal cortex have not yet been demonstrated, but could be present, and could contribute to the inhibitory responses recorded here. Note, however, that the presence of direct inhibition is not necessary to explain the evoked IPSPs reported here: Local candidate inhibitory neurons are present, and they have the necessary anatomical and physiological properties for a feedforward inhibitory circuit.

Although biased sampling by the micropipet electrodes may have contributed to the small number of candidate inhibitory neurons encountered ( 2 out of 64 cells in this series of recordings), the results suggest that inhibitory cells constitute only a small proportion of neurons within the entorhinal cortex and subicular complex. Their powerful physiological action would be explained by divergence of their axonal domains-similar to the hippocampus and dentate gyrus (Schwartzkroin and Mathers, 1978; Struble et al., 1978; Finch et al., 1983)-so that one inhibitory neuron could contact many principal neurons. Convergence of the input of many inhibitory cells onto one principal cell is also likely since there is no evidence here that one or a few inhibitory cells could produce the large principal cell IPSPs. In the guinea pig hippocampal field CA3, Miles and Wong (1984) have estimated that one pyramidal cell can be contacted by up to 15 inhibitory neurons. 
In conclusion, we have presented in vivo neurophysiological evidence that entorhinal and subicular complex principal neurons are inhibited in a feedforward manner. This is shown most clearly here by inputs originating from the hippocampus but is likely to be the case for other inputs as well, for example, the LOT and the amygdala (Wouterlood et al., 1985; Colino and de Molina, 1986; Finch et al., 1986b). The results indicate that candidate inhibitory neurons within the entorhinal cortex and subicular complex are excited by afferent fibers and that they then contact and inhibit local principal cells. Since these afferents also excite the principal neurons, the circuitry would result in a damping of principal cell excitation after a latency of about $5 \mathrm{msec}$. The inhibitory effects of a feedforward circuit could be produced whether or not an afferent signal produced action potentials in principal cells, provided that action potentials were produced in inhibitory neurons. This is not unreasonable, since candidate inhibitory neurons in the dentate gyrus and HPC have been shown to produce action potentials in response to activation of afferents at stimulus intensities subthreshold for spike initiation in principal cells (Buzsàki and Eidelberg, 1982; Lacaille et al., 1987). Feedforward circuitry also allows for the convergence of inhibitory influences, even in cases in which inputs do not reach the threshold for excitation of principal cells (again provided that action potentials were produced in inhibitory neurons). Thus, feedforward inhibition, but not feedback inhibition, allows for convergence of inhibitory influences when an input is suprathreshold to inhibitory neurons and subthreshold to principal neurons. The convergence of inhibition is likely to be significant for the role of the entorhinal cortex and subicular complex in integrating and processing information from different sources (Van Hoesen, 1982). Feedforward inhibitory circuitry would also be significant in shaping the response of the entorhinal cortcx to repetitive, synchronous activation such as is likely to occur during temporal lobe seizures, and must be taken into account when interpreting the response of entorhinal neurons to pharmacological agents such as anticonvulsants.

\section{References}

Alder, E. B., and E. B. Roessler (1964) Introduction to Probability and Statistics, W. H. Freeman, San Francisco.

Alger, B. E., and R. A. Nicoll (1982) Feed-Forward dendritic inhibition in rat hippocampal pyramidal cells studied in vitro. J. Physiol. (Lond.) 328: 105-123.

Alonso, A., and C. Köhler (1982) Evidence for separate projections of hippocampal pyramidal and non-pyramidal neurons to different parts of the septum in the rat brain. Neurosci. Lett. 31: 209-214.

Alonso, A., and C. Köhler (1984) A study of the reciprocal connections between the septum and the entorhinal area using anterograde and retrograde axonal transport methods in the rat brain. J. Comp. Neurol. 225: 225-327.

Andersen, P. (1975) Organization of hippocampal neurons and their interconnections. In The Hippocampus, Vol. 1, R. L. Isaacson and K. II. Pribram, eds., pp. 155-175, Plenum, New York.

Ashwood, T. J., B. Lancaster, and H. V. Wheal (1984) In vivo and in vitro studies on putative interneurones in the rat hippocampus: Possible mediators of feed-forward inhibition. Brain Res. 293: 279291.

Babb, T. L., W. J. Brown, W. Kupfer, and J. Pretorius (1986) Monosynaptic commissural feed-forward GABA-inhibition of fascia dentata in rat hippocampus. Soc. Neurosci. Abstr. 12: 1528.

Beckstead, R. M. (1978) Afferent connections of the entorhinal area in the rat as demonstrated by retrograde cell-labeling with horseradish peroxidase. Brain Res. 152: 249-264.

Buzsàki, G. (1984) Feed-forward inhibition in the hippocampal formation. Prog. Neurobiol. 22: 131-153.

Buzsàki, G., and E. Eidelberg (1981) Commissural projection to the dentate gyrus of the rat: Evidence for feed-forward inhibition. Brain Res. 230: 346-350.

Buzsàki, G., and E. Eidelberg (1982) Direct afferent excitation and long-term potentiation of hippocampal interneurons. J. Neurophysiol. 48: 597-607.

Colino, A., and F. de Molina (1986) Inhibitory response in entorhinal and subicular cortices after electrical stimulation of the lateral and basolateral amygdala of the rat. Brain Res. 378: 416-419.

Eccles, J. C. (1957) The Physiology of Nerve Cells, The Johns Hopkins University Press, Baltimore.

Egan, T. M., and A. North (1986) Acetylcholine hyperpolarizes central neurones by acting on an $\mathrm{M}_{2}$ muscarinic receptor. Science 319: 405407.

Finch, D. M., and T. L. Babb (1977) Response decrement in a hippocampal baskct cell. Brain Res. 130: 354-359.

Finch, D. M., and T. L. Babb (1980a) Inhibition in subicular and entorhinal principal neurons in response to electrical stimulation of the fornix and hippocampus. Brain Res. 196: 89-98.

Finch, D. M., and T. L. Babb (1980b) Neurophysiology of the caudally directed hippocampal efferent system in the rat: Projections to the subicular complex. Brain Res. 197: 11-26.

Finch, D. M., N. L. Nowlin, and T. L. Babb (1983) Demonstration of axonal projections of neurons in the rat hippocampus and subiculum by intracellular injection of HRP. Brain Res. 271: 201-216.

Finch, D. M., E. E. Wong, E. L. Derian, and T. L. Babb (1986a) Neurophysiology of limbic system pathways in the rat: Projections from the subicular complex and hippocampus to the entorhinal cortex. Brain Res. 397: 205-213.

Finch, D. M., E. E. Wong, E. L. Derian, X-.H. Chen, N. L. NowlinFinch, and L. A. Brothers (1986b) Neurophysiology of limbic system pathways in the rat: Projections from the amygdala to the entorhinal cortex. Brain Res. 370: 273-284.

Haberly, L. B., and J. M. Bower (1984) Analysis of association fiber system in piriform cortex with intracellular recording and staining techniques. J. Neurophysiol. 51: 90-112.

Kandel, E. R., W. A. Spencer, and F. J. Brinley, Jr. (1961) Electrophysiology of hippocampal neurons. I. Sequential invasion and synaptic organization. J. Neurophysiol. 24: 225-242.

Kerr, D. I. B., and B. J. Dennis (1972) Collateral projection of the lateral olfactory tract to entorhinal cortical areas in the cat. Brain Res. 36: 399-403.

Knowles, W.D., and P. A. Schwartzkroin (1981) Local circuit synaptic interactions in hippocampal brain slices. J. Neurosci. 1: 318-322.

Köhler, C. (1985) A projection from the deep layers of the entorhinal area to the hippocampal formation in the rat brain. Neurosci. Lett. 56: $13-19$.

Kriegstein, A. R., and B. W. Connors (1986) Cellular physiology of the turtle cortex: Synaptic properties and intrinsic circuitry. J. Neurosci. 6: 178-191.

Lacaille, J. C., A. L. Mueller, D. D. Kunkel, and P. A. Schwartzkroin (1987) Local circuit interactions between oriens/alveus interneurons and CAl pyramidal cells in hippocampal slices: Electrophysiology and morphology. J. Neurosci. 7: 1979-1993.

Llinás, R., and M. Sugimori (1984) Simultaneous intracellular and dendritic recording from Purkinje cells in vitro: Dynamic soma-dendritic coupling. Soc. Neurosci. Abstr. 10: 659.

Lorenté de No, R. (1933) Studies on the structure of the cerebral cortex. I. The area entorhinalis. J. Psychol. Neurol. (Lpz.) 45: 381-438.

Miles, R., and R. K. S. Wong (1984) Unitary inhibitory synaptic potentials in the guinea-pig hippocampus in vitro. J. Physiol. (Lond.) 356: 97-113.

Nicoll, R. A., and N. R. Newberry (1984) A possible postsynaptic inhibitory action for $\mathrm{GABA}_{\mathrm{B}}$ receptors on hippocampal pyramidal cells. Neuropharmacology 23: 849-850.

Paxinos, G., and C. Watson (1982) The Rat Brain in Stereotaxic Coordinates, Academic, New York.

Room, P., H. J. Groenewegen, and A. H. M. Lohman (1984) Inputs from the olfactory bulb and olfactory cortex to the entorhinal cortex in the cat. Exp. Brain Res. 56: 488-496.

Ruch, T. C., H. D. Patton, J. W. Woodbury, and A. L. Towe (1965) Neurophysiology, W. B. Saunders, Philadelphia.

Satou, M., K. Mori, Y. Tazawa, and S. F. Takagi (1983) Interneurons mediating fast postsynaptic inhibition in pyriform cortex of the rabbit. J. Neurophysiol. 50: 89-101.

Schwartzkroin, P. A., and D. D. Kunkel (1985) Morphology of iden- 
tified interneurons in the CAl regions of guinea pig hippocampus. $\mathrm{J}$. Comp. Neurol. 232: 205-218.

Schwartzkroin, P. A., and L. H. Mathers (1978) Physiological and morphological identification of a nonpyramidal hippocampal cell type. Brain Res. 157: 1-10.

Schwerdtfeger, W. K. and E. Buhl (1986) Various types of non-pyramidal hippocampal neurons project to the septum and contralateral hippocampus. Brain Res. 386: 146-154.

Seress, L., and C. E. Ribak (1983) GABAergic cells in the dentate gyrus appear to be local circuit and projection neurons. Exp. Brain Res. 50: 173-182.

Seress, L., and C. E. Ribak (1984) Direct commissural connections to the basket cells of the hippocampal dentate gyrus: Anatomical evidence for feed-forward inhibition. J. Neurocytol. 13: 215-225.

Seress, L., and C. E. Ribak (1985) A combined Golgi-electron microscopic study of non-pyramidal neurons in the CAl area of the hippocampus. J. Neurocytol. 14: 717-730.

Shipley, M. T. (1974) Presubiculum afferents to the entorhinal area and the Papez circuit. Brain Res. 67: 162-168.

Spencer, W. A., and E. R. Kandel (1961) Hippocampal neuron responses to selective activation of recurrent collaterals of hippocampofugal axons. Exp. Neurol. 4: 149-161.
Struble, R. G., N. L. Desmond, and W. B. Levy (1978) Anatomical evidence for interlamellar inhibition in the fascia dentata. Brain Res. 152: $580-585$.

Swanson, L. W., and W. M. Cowan (1977) An autoradiographic study of the organization of the efferent connections of the hippocampal formation in the rat. J. Comp. Neurol. 172: 49-84.

Van Hoesen, G. W. (1982) The parahippocampal gyrus. New observations regarding its cortical connections in the monkey. Trends Neurosci. $5: 345-350$.

Woody, C. D., E. Gruen, and K. McCarley (1984) Intradendritic recordings from neurons of motor cortex of cats. J. Neurophysiol. 51 : 925-938.

Wouterlood, F. G., and J. Nederlof (1983) Terminations of olfactory afferents on layer II and III neurons in the entorhinal area: Degeneration-Golgi-electron microscopic study in the rat. Neurosci. Lett. 36: $105-110$.

Wouterlood, F. G., E. Mugnaini, and J. Nederlof (1985) Projections of olfactory bulb efferents to layer I GABAergic neurons in the entorhinal area. Combination of anterograde degeneration and immunoelectron microscopy in rat. Brain Res. 343: 283-296. 